\title{
LOAN SPREADS AND UNEXPECTED EARNINGS
}

\author{
DISSERTATION
}

Presented in Partial Fulfillment of the Requirements for

The Degree Doctor of Philosophy in the Graduate

School of The Ohio State University

By

Jiewei Yu, B.A., M.A.

$* * * * *$

The Ohio State University

2007

Dissertation Committee:

Approved by

Professor Anne Beatty, Adviser

Professor Rudi Fahlenbrach

Adviser

Graduate Program in

Professor Rick Johnston Accounting and Management Information Systems

Professor Siew Hong Teoh 


\begin{abstract}
This study explores whether banks have superior information to financial analysts about borrowers' future earnings at the financing decision stage. The results suggest that at the loan initiation, banks have incorporated into loan spreads borrowers' future earnings news, information that is unexpected by analysts. The sensitivity of loan spreads to unexpected earnings varies cross-sectionally and over time in the same direction as the predicted changes in banks' relative information advantages. Further tests show that the results are robust to alternative measures of unexpected earnings, and are unlikely to be driven by correlated omitted risk factors.
\end{abstract}


Dedicated to my wife and my parents 


\section{ACKNOWLEDGMENTS}

I am very grateful to my adviser, Professor Anne Beatty, for her encouragement, intellectual support and insightful guidance in the development of this dissertation. I am indebted to Professor Rudi Fahlenbrach, Professor Rick Johnston and Professor Siew Hong Teoh for their efforts in guiding and assisting with this research effort.

I would like to thank the faculty of the department of Accounting \& MIS and the fellow graduate students for their encouragement and support in this effort.

I also wish to thank the seminar participants at Lehigh University, Miami University, Michigan State University, MIT, Northwestern University, Southern Methodist University, The Ohio State University, University of Chicago, University of Colorado at Boulder, University of Michigan, University of Minnesota, University of Rochester, University of Toronto, University of Wisconsin at Madison, the 2006 AAA annual conference at Washington D.C. and the 2007 CARE conference at Yountville, California for helpful comments and suggestions. 


\title{
VITA
}

\author{
September 28, 1975................. Born - Ningbo, P.R. China \\ 1998.................................... in Economics, Fudan University

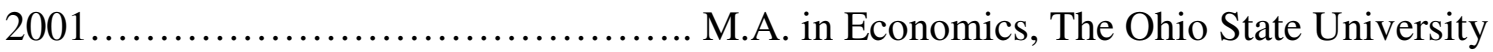 \\ 2001 - present .................... Graduate Research and Teaching Associate, \\ The Ohio State University
}

\section{FIELDS OF STUDY}

Major Field: Accounting and Management Information Systems

Minor Fields: Microeconomics, Finance, Statistics 


\section{TABLE OF CONTENTS}

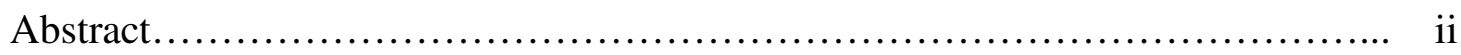

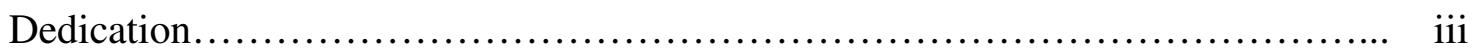

Acknowledgments ................................................... iv

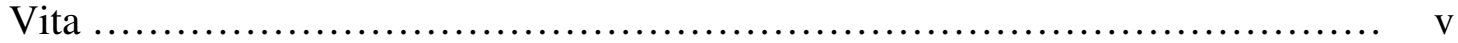

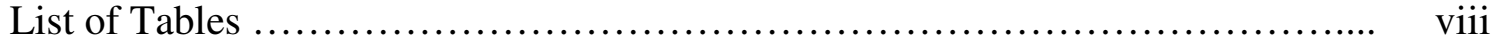

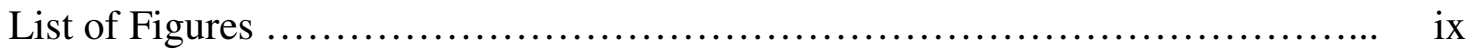

\section{Chapters:}

1. Introduction......................................................... 1

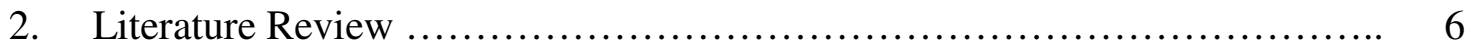

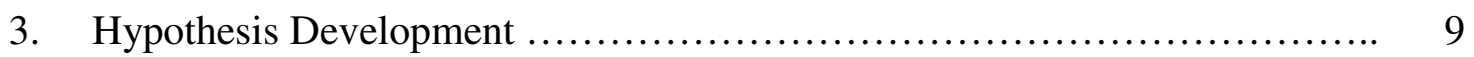

3.1 The negative association between loan spreads and unexpected earnings .. 9

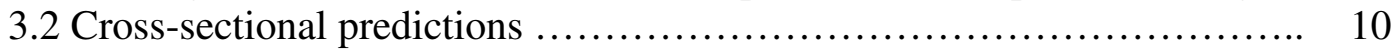

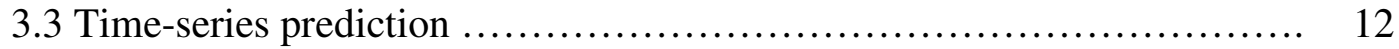

4. Research Design ..................................................... 13

4.1 Sample construction ......................................... 13

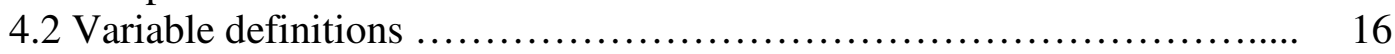

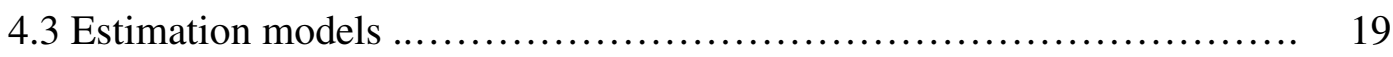

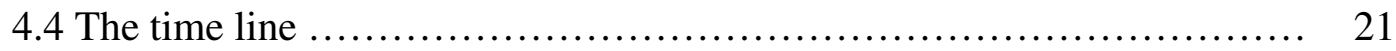


5. Results ...................................................................... 23

5.1 Descriptive statistics .................................................................... 23

5.2 Multivariate analyses ................................................. 29

5.3 Cross-sectional variations ........................................... 31

5.4 Changes before and after Reg FD ................................ 34

5.5 Risk or information? ............................................ 36

6. Sensitivity Analyses ............................................................. 39

6.1 Alternative measures of unexpected earnings.......................................... 39

6.2 Tests of alternative interpretations................................. 44

6.3 Further evidence of costly private information production...................... 48

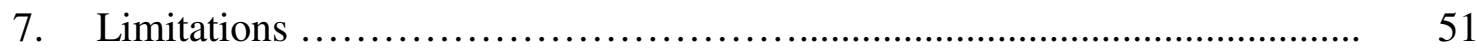

7.1 The sources of the superior information............................................... 51

7.2 Active information producer or passive information receiver? ........... 53

7.3 Thoughts on alternative ways to triangulate the research question........ 55

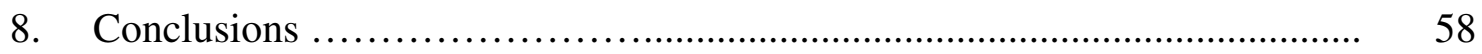

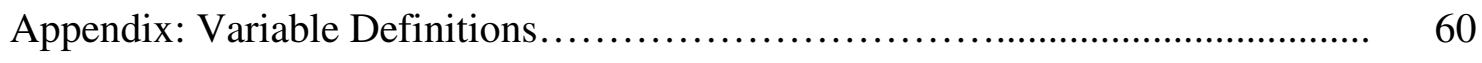

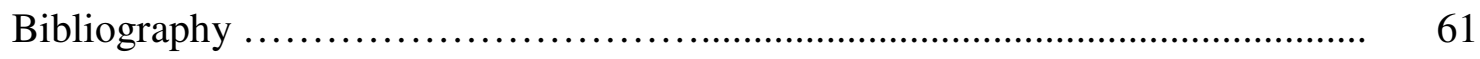




\section{LIST OF TABLES}

Table

Page

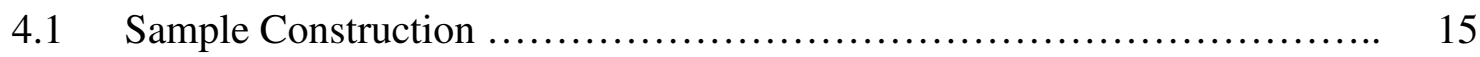

$5.1 \quad$ Descriptive statistics ............................................... 25

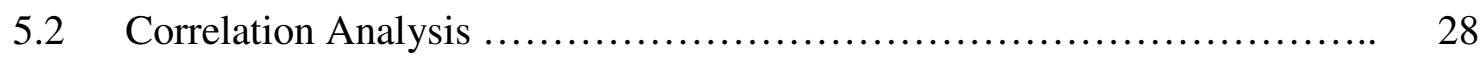

5.3 Multivariate regression of loan spreads on unexpected earnings ........... 30

5.4 Cross-sectional analyses of banks' relative information advantage ......... 33

5.5 Inter-temporal analysis of banks' relative information advantage .......... 35

5.6 Multivariate regression of loan spreads on unexpected earnings one-quarter

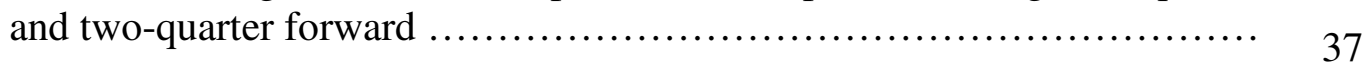

6.1 Alternative measures of unexpected earnings ......................... 43

6.2 Tests of alternative interpretations.................................................... 47

6.3 Further evidence of costly private information production................ 50 


\section{LIST OF FIGURES}

Figure

Page

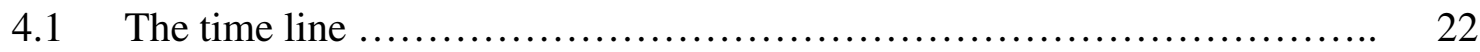




\section{CHAPTER 1}

\section{INTRODUCTION}

Contemporary theories of financial intermediation highlight the special role of banks in private information production and mitigation of informational asymmetries in an imperfect capital market (see Leland and Pyle, 1977; Campbell and Kracaw, 1980; Allen, 1990). One important implication of these theories is that, at the financing decision stage, banks "know more about a company's prospects than other investors do" (James, 1987, page 217). I label this the "superior information hypothesis."

An alternative theoretical view recognizes that there are other solutions to the information problem. Given the information spillover from public signals, private information production by banks can be efficient only when other information sources are noisy (Berlin and Loeys, 1988; Sunder, 2006). In the extreme, Fama (1980) argues that banks can exist as merely passive portfolio managers. Campbell and Kracaw (1980, page 864) cite this argument as "a potentially powerful null hypothesis."

The tension between these two views is likely to be the highest for publicly-traded U.S. firms with analyst coverage, where both financial reporting and analyst following are well-known solutions to the "lemons" problem (Akerlof, 1970), and both provide valuable information services to the capital market (Healy and Palepu, 2001). Frankel, 
Kothari and Weber (2006) further show that the informativeness of analyst reports complements that of financial statements. A rich public information environment mitigates banks' relative information advantage via two channels: the improved information set of other investors, and the reduced incentive to obtain private signals, because banks are granted with low-cost alternatives to assess and control for default risk (substitution effect). For example, banks can use stock performance or credit rating as a screening device (Sunder, 2006), or set tight financial covenant thresholds as "trip wires" (Dichev and Skinner, 2002). Consequently, this paper examines the following research questions: (1) For publicly-traded U.S. firms with analyst following, does the superior information hypothesis still hold? (2) How do banks' economic incentives and disclosure regulations affect banks' relative information advantage?

Two strands of prior empirical research have explored the superior information hypothesis. One strand investigates whether the stock market reacts favorably to bank loan announcements (James, 1987; Lummer and McConnell, 1989; Billet, Flannery and Garfinkel, 2006), while the other examines whether the secondary loan market is more informationally efficient than the equity market (Altman, Gande and Sauders, 2004; Allen, Guo and Weintrop, 2004; Allen and Gottesman, 2005). However, the former approach is confounded by a self-selection bias, as firms are more likely to make voluntary announcements when loan terms are favorable. The latter approach, by construction, mainly captures banks' ex post information advantage, that is, after the loan is initiated and then traded. It also lacks power due to the relative illiquidity of the secondary loan market. As a result, findings of the above studies are largely mixed. What 
is more relevant, but remains missing from the literature, is a more direct test of banks' $e x$ ante information advantage before loans are granted.

My study fills this void, by focusing on the primary bank loan market and banks' information advantage at the financing decision stage. It also avoids the aforementioned self-selection bias by obtaining the loan contracts from mandatory SEC filings. Exploiting detailed loan contract data and a new research design, this study provides a more direct test of the superior information hypothesis by exploring whether at the loan initiation banks have "priced-in" borrowers' future earnings news, news that is unexpected by other investors.

Focusing on publicly-traded U.S. borrowers with equity analyst coverage, I find robust evidence consistent with the superior information hypothesis. ${ }^{1}$ In particular, I document that banks set loan spreads at the loan initiation as if they have anticipated the sign and magnitude of borrowers' future earnings that is unexpected by equity analysts. Unexpected earnings are significantly negatively associated with loan spreads, after controlling for forecast complexity and bias, earnings volatility, credit rating, and other loan- or firm-specific determinants of credit risk. Consistent with banks' asymmetric payoff function, loan spreads are significantly more sensitive to negative unexpected earnings than to positive ones. Moreover, the results suggest that the sensitivity of loan spreads to unexpected earnings varies cross-sectionally and over time in predictable ways that are consistent with banks' economic incentives and regulatory environment: (1) loan

\footnotetext{
${ }^{1}$ Leuz and Verrecchia (2000) argue that under current U.S. GAAP the disclosure environment for publicly traded U.S. firms is "already rich" and cross-sectional variation in voluntary disclosure among these firms is unlikely to have discernable economic consequences. Here I focus on this first-order effect of mandatory disclosure.
} 
spreads are significantly less sensitive to unexpected earnings for secured loans and firms with high analyst following, where banks have less incentive to engage in costly private information production; (2) loan spreads are significantly more sensitive to unexpected earnings for firms with income-increasing abnormal accruals, where more bank scrutiny is required and the lead bank in the loan syndicate retains a larger stake to commit to effective ex ante evaluation; (3) the sensitivity is significantly higher after Regulation Fair Disclosure (hereafter Reg FD), when private communications between managers and analysts are prohibited, but banks are exempted from the regulation.

Supplementary analyses exploit the timing difference in information availability to differentiate whether the results above capture information advantage or correlated omitted risk factors. I find that: (1) the results become weaker if unexpected earnings are measured one quarter forward, when uncertainty gradually resolves and some private information at the loan initiation has been revealed to the public; (2) the results disappear if unexpected earnings are measured two quarters forward, when most firms have filed bank loan contracts with the SEC. These findings lend more support to the information story, since risk factors are unlikely to vanish over a short period of time.

Finally, sensitivity analyses suggest that the results are robust to using abnormal returns around earnings announcement as an instrument for unexpected earnings, to using analysts' annual forecasts instead of quarterly forecasts, and to using alternative deflators. Sub-sample analyses further indicate that the results are not driven by a mechanical association, by knowing the loan purpose, or by banks' exclusive access to monthly financial statements. 
This paper contributes to the literature in several ways. First, I take a new approach and provide more direct evidence consistent with the superior information hypothesis, which is in contrast to the mixed findings in the prior literature. The new research design and detailed loan contract data enable me to circumvent the common limitations that have contaminated previous studies. Second, Holthausen and Watts (2001, page 52) have called for more research on "the nature and strength of the other forces (besides the demand of equity investors) that shape accounting." Since the demand of lenders is an important force that shape accounting (Ball, Robin and Sadka, 2005), this paper answers the call by investigating how lenders' information environment may be different from that of equity investors. Finally, since banks' information environment is not affected by Reg FD, my finding of widened relative information advantage after Reg FD provides cleaner evidence that the information environment for equity analysts has deteriorated after the regulation. This result helps inform the debate on Reg FD and contributes to this growing body of literature.

The rest of the paper is organized as follows. Section 2 reviews the related literature. Section 3 develops the hypotheses. Section 4 describes the research design. Section 5 presents the results. Section 6 reports the sensitivity analyses. Section 7 discusses limitations and thoughts for future research. Section 8 concludes the paper. 


\section{CHAPTER 2}

\section{LITERATURE REVIEW}

This study is related to two strands of literature. The first strand examines the stock market reactions to firms' voluntary announcements of bank loan agreements. The rationale is as follows. If banks have superior information, they will screen borrowers based on that information. By granting or renewing a loan, banks implicitly provide a certification of the financial condition of the borrower. Therefore, bank loan announcements should convey a favorable signal to the market. Consistent with this prediction, a series of studies (James, 1987; Lummer and McConnell, 1989; Billet, Flannery and Garfinkel, 1995) have reported a significantly positive two-day abnormal return for bank loan announcements.

One limitation of these studies is that firms choose to voluntarily disclose the loan agreements before filing with the SEC. To the extent that firms are more likely to make announcements when the loan terms are favorable, there will be a bias in favor of finding the positive market reactions to loan announcements during a short-window. In other words, the self-selection problem may generate a biased sample. Without appropriate correction for endogeneity, the results are hard to interpret. In fact, using a long event window, Billet et al. (2006) document that firms announcing bank financing suffer 
negative abnormal stock returns instead during the three-year post-announcement period, which is not different from the findings for equity offerings or public debt issuances.

In this study, I avoid the self-selection bias by obtaining the loan agreements from mandatory SEC filings. Public firms are required to file all material contracts with the SEC, including bank loan agreements.

The second strand of research compares the informational efficiency of the secondary syndicated loan market with that of the equity or bond market. The argument is that if banks have superior information about borrowers, the information should be incorporated in the loan price on the secondary loan market before it is released publicly and reflected in the equity or bond price.

Consistent with this argument, Altman et al. (2004) find that the secondary loan market leads the bond market in reacting to bankruptcy and default announcements. Similarly, Allen et al. (2004) report significant price movements in the secondary loan market four weeks prior to the announcement of earnings declines, which coincides with the timing of monthly covenant reports to banks. On a day-to-day basis, however, Allen and Gottesman (2005) find contrary evidence that equity returns lead and "Granger cause" secondary loan returns.

This approach is a joint test of the superior information hypothesis and the implicit assumption that the secondary loan market is otherwise as efficient as the equity or bond market. The latter has yet to be established in order to draw unambiguous inferences. Given the relative illiquidity of the secondary loan market, this assumption is unlikely to hold. More importantly, this approach mainly captures banks' ex post 
information advantage. After loans are granted, banks typically receive monthly covenant reports. So it is not surprising that during the loan period, banks learn news about borrowers' forthcoming defaults and earnings declines ahead of equity investors, who only receive quarterly financial reports.

Because banks' ex ante information advantage is essential in the theories to derive banks' special role in mitigating information asymmetries, this paper focuses on the primary loan market instead and examines whether banks have superior information before loans are granted. 


\section{CHAPTER 3}

\section{HYPOTHESIS DEVELOPMENT}

\subsection{The negative association between loan spreads and unexpected earnings}

At the loan initiation, banks set the interest rates (measured as loan spreads) as a function of their private signals as well as all available public information. When banks' private signals about future earnings are sufficiently superior to those of analysts, a significant portion of earnings unexpected by analysts will be incorporated into loan spreads. We should observe that unexpected earnings are correlated with loan spreads over and above all public indicators of default risk. The lower the unexpected earnings -that is, the more negative the earnings shocks predicted by banks' private signals -- the higher interest rates will be charged on bank loans. In the extreme, when the private information allows banks to perfectly predict unexpected earnings, this negative association will be the strongest. In contrast, if banks do not have an informational advantage over analysts, or analysts have superior information to banks, then unexpected earnings will be merely noise to banks and on average should have no effect on loan spreads. This leads to my first hypothesis:

H1: Ceteris paribus, loan spreads are negatively associated with unexpected earnings. 


\subsection{Cross-sectional Predictions}

Private debt claims are different from equity claims in that banks often do not benefit from borrowers' large profits, but may be seriously hurt by large losses (Ball, 2001). Hence, banks inherently care more about downside risk and get more actively involved when borrowers are performing poorly. In addition, expecting that borrowers have incentives to disclose more good news and to withhold bad news during the contracting process (Kothari, Shu and Wysocki, 2005; Pae, 2005), banks may priceprotect themselves by putting more weight on private information that signals bad news when setting loan spreads. This leads to my second hypothesis:

H2: Ceteris paribus, loan spreads are more sensitive to negative unexpected earnings than to positive unexpected earnings.

Secured loans are typically very risky in the sense that there is increased uncertainty concerning borrowers' future performance and banks' private signals are relatively noisier (Berger and Udell, 1990). Therefore, banks tend to have less superior information compared to analysts in the case of secured loans. This is reinforced by the fact that once the loan is secured, banks might devote fewer resources in private information production (Manove, Padilla, and Pagano, 2001). These arguments yield the third hypothesis:

H3: Ceteris paribus, the sensitivity of loan spreads to unexpected earnings is lower for secured loans than non-secured loans.

Berlin and Loeys (1988) contend that the value of private information production

by banks depends on the reliability of other indicators of borrower type. Further 
investigation of the firm is only valuable when both the prior probability of the firm type and the informativeness of other indicators are quite low. In addition, Best and Zhang (1993) find some empirical support that banks invest in costly private information production only when alternative information sources are noisy.

Firms with high analyst following tend to have more informative disclosure (Lang and Lundholm, 1996), and stock prices of these firms incorporate information on accruals and cash flows more quickly (Barth and Hutton, 2000).

Consequently, for borrowers with high analyst following, banks will have lower relative informational advantage over analysts. This leads to my fourth hypothesis:

H4: Ceteris paribus, the sensitivity of loan spreads to unexpected earnings is lower for borrowers with higher analyst following.

Sufi (2007) argues that borrowers reporting income-increasing abnormal accruals operate in a high information asymmetry environment and require more rigorous screening and monitoring by banks. Consistent with this argument, he documents that lead banks retain significantly higher shares of the syndicated loan for these borrowers to commit to effective ex ante evaluation and ex post monitoring. Moreover, Moerman (2006) finds that firms with income-increasing abnormal accruals tend to violate debt covenants, or have financial numbers just above the covenant threshold. Armed with this knowledge, banks have incentives to give these firms more scrutiny before loans are granted. These arguments yield the following hypothesis:

H5: Ceteris paribus, the sensitivity of loan spreads to unexpected earnings is higher for firms with income-increasing abnormal accruals. 


\subsection{Time-series Prediction}

On October 23, 2000, the SEC enacted Reg FD, prohibiting selective disclosure of material information to financial analysts. If the information disclosed in closed conference calls before Reg FD is primarily bad news or proprietary information, then after Reg FD firms will have incentives to withhold the information (Kothari et al., 2005; Dye, 1985), now that private communications are not allowed. To the extent that analysts cannot fully recover the information loss via independent research, their information set is likely to be smaller. Consistent with this, $\mathrm{Ke}$ and $\mathrm{Yu}$ (2005) find that the informativeness of analysts' downgrade recommendation declines significantly after Reg FD for closed conference call firms. Wang (2006) reports that most firms replaced private earnings guidance with nondisclosure after Reg FD, resulting in significant deterioration in analysts' information environment.

If the public information environment deteriorates after Reg FD, then private information becomes more valuable and banks will find it efficient to invest more in private information production (Berlin and Loeys, 1988; Best and Zhang, 1993). Meanwhile, since commercial banks are exempted from Reg FD as contractual parties, they also have better access to information than equity analysts. For instance, banks can still have private communications with managers after Reg FD while analysts cannot. As a result, the information gap between the two parties should increase and unexpected earnings should be more strongly associated with loan spreads. My last hypothesis is:

H6: Ceteris paribus, the sensitivity of loan spreads to unexpected earnings is higher after Reg FD than before Reg FD. 


\section{CHAPTER 4}

\section{RESEARCH DESIGN}

\subsection{Sample Construction}

Table 4.1 summarizes the steps employed in the sample selection process. LPC Dealscan database compiles loan price and non-price terms from SEC filings. I obtain from Dealscan 20,153 bank loan facilities from January 1987 to June 2005 borrowed by publicly-traded U.S. corporations: (1) The borrower must be a publicly-traded firm, that is, the borrower's ticker is not missing and correctly matches CRSP ticker; ${ }^{2}$ (2) The borrower country must be the United States; (3) The borrower type must be coded as “corporation," which excludes banks, insurance companies and utility firms. Utility firms are often heavily regulated with stable cash flows and predictable earnings. As a result, information asymmetry is rarely a problem for these firms, and their credit risks are unusually low relative to their leverage. As for banks and insurance companies, regulatory monitoring and explicit investor insurance schemes such as deposit insurance may strongly influence the credit decisions for these borrowers. Their debt-like liabilities may not be strictly comparable to the debt issued by non-financial firms. I exclude them

\footnotetext{
${ }^{2}$ Besides ticker, the only other identifier available on Dealscan is company name. An alternative way to merge Dealscan with CRSP or Compustat, therefore, is to match on company name.
} 
from the current analysis to make sure that the results are not driven by these special observations. For future research, it may be interesting to examine banks as a separate sample, given their dual role of borrowers and lenders.

To calculate unexpected earnings (UE), analysts' consensus EPS forecasts and the actual EPS values are needed. I further require each analyst's most recent forecast be issued after the facility active date to be included in the consensus forecast calculation. The requirement of coverage by I/B/E/S Detail History File significantly reduces the sample size. Only 11,629 observations have non-missing UE, among which 11,356 bank loan facilities have non-missing total assets (item 44) on the COMPUSTAT Industrial Quarterly File.

Some firms in the sample have multiple bank loan deals during the same quarter, and the same deal may include multiple facilities. As a result, some firm-quarters are likely to be over-represented in the sample. This could also cause cross-sectional dependence in the regression error terms. To address this concern, I select the first deal for each firm-quarter and randomly include in the sample one facility for each deal. This further reduces the sample to 8,016 observations. The results are qualitatively the same if I do not impose this restriction.

The additional requirement of non-missing data for all control variables results in a final sample of 5,859 observations. I use this sample to compute descriptive statistics and test the first hypothesis (H1). Depending on the independent variables used, however, the sample size in the subsequent regression analyses may become smaller than 5,859 because of stricter data requirements imposed by the new variables. 
Dealscan bank loan facilities borrowed by publicly-traded U.S. corporations from January 1987 to June 2005

Less: Firm-quarters with missing I/B/E/S coverage

Less: Firm-quarters where no analyst updates his/her forecast for current quarter EPS after the loan initiation date, according to I/B/E/S

Detail History File

Less: Firm-quarters with missing actual EPS on I/B/E/S Detail History File

Less: Firm-quarters with missing total assets (item 44) on COMPUSTAT Industrial Quarterly File

Less: Requiring the first bank loan deals for each firm-quarter

Less: Restricting one bank loan facility for each deal

Less: Firm-quarters with missing data on any control variable in Model (1)

Final Sample

\section{Table 4.1 Sample Construction}

Notes: Final Sample is the sample used to calculate descriptive statistics and run the multivariate regression to test the first hypothesis (H1). COMPLEX, EARN_VOL and RET_VOL are the main drivers of the reduction in sample size from 8,016 to 5,859 in the last stage of sample selection. See appendix for variable definitions. Depending on the independent variables used, the sample size in the subsequent regression analyses may become smaller because of stricter data requirements imposed by the new variables. For example, the cross-sectional analysis to test $\mathrm{H} 5$ requires non-missing data for abnormal accruals, and the forward regressions in Table 5.6 require unexpected earnings measured at quarter $t+1$ or quarter $t+2$ earnings announcement date. Consequently, the sample size for these regressions may be different from 5,859 . 


\subsection{Variable Definitions}

\subsubsection{Loan spread}

The main objective of the analysis is to explore whether banks incorporate the borrower's future unexpected earnings into the interest rate at the loan initiation. Therefore, the dependent variable for all regressions is the interest rate of each bank loan. Following Bharath, Sunder and Sunder (2007), I measure the interest rate using "all-inspread drawn" (AISD) from LPC Dealscan database, which is the mark-up over LIBOR paid by the borrower on all drawn lines of credit. LIBOR is a floating rate. Analogous to market return in the equity case, it fluctuates as the macroeconomic conditions change. As a result, by using this loan spread measure, I have adjusted for (at least to a certain extent) economy-wide shifts in the cost of debt.

\subsubsection{Unexpected earnings}

The main independent variable is unexpected earnings (UE). Following O'Brien (1988), I use analysts' consensus earnings forecast as a proxy for other investors' expectation about firms' future earnings. Brown and Rozeff (1978) and Givoly (1982) have established that analysts' consensus earnings forecast performs better than timeseries models of earnings, and that it is a superior surrogate for market expectations in part because analysts are able to incorporate firm and economy news into their forecasts in a timely manner.

For each firm-quarter, I choose the most recent EPS forecast for each analyst. To facilitate comparison and to approximate the lower bound of banks' relative informational advantage over analysts, I restrict all analysts' EPS forecasts for quarter t to 
be made after the loan initiation date. The EPS forecasts with estimate dates before or at the loan initiation date are deleted. To the extent that uncertainty gradually resolves as time goes by and analysts can update their forecasts based on newer information, it will bias against rejecting the null of no superior information. I then obtain the consensus analyst forecast for each firm-quarter by taking the median ${ }^{3}$ of the remaining most recent analysts' forecasts. UE is measured at the quarter $t$ earnings announcement date as the difference between the actual EPS and the consensus analyst forecast of EPS, deflated by the absolute value of the consensus analyst forecast of EPS. To ensure comparability, actual EPS is also taken from I/B/E/S Detail History file.

Univariate statistics indicate that UE is highly skewed and has large outliers, with the lowest value less than -91 and the highest value more than 37 , which can be translated to percentage forecast errors of $-9100 \%$ and $3700 \%$ respectively. I winsorize UE at the top and bottom $1 \%$ to mitigate the influence of extreme values. ${ }^{4}$

\subsubsection{Control variables}

The control variables include loan characteristics such as loan size (FSIZE), loan maturity (MATURITY), secured loan (SECURE) and loan purpose (TAKEOVER), as well as firm-specific credit risk factors such as leverage (LEVERAGE), total assets (ASSETS), Tobin's Q (TobinQ), prior performance (LAGRET), S\&P senior debt credit rating (RATING) and a dichotomous variable that equals 1 for firms that do not have a credit rating, 0 otherwise (D_NR). ${ }^{5}$ All of these control variables have been shown in the

\footnotetext{
${ }^{3}$ Median measure is less susceptible to outliers. The results are virtually the same using the mean measure. ${ }^{4}$ The results are robust to winsorizing UE based on an alternative cutoff of top and bottom 5\%, as well as an intuitive cutoff point of 1 at the top and -1 at the bottom (100\% forecast error).

${ }^{5}$ The results are robust to using ROA (item 8 / item 44) instead of LAGRET to measure prior performance.
} 
prior literature to be important determinants of loan spreads (Bharath et al., 2007; Asquith, Beatty and Weber, 2005). Variable definitions are detailed in the Appendix.

A possible concern is that unexpected earnings also capture the confounding factor of forecast complexity and operational uncertainty. Consider a firm whose business model is so complex, and whose operating environment is so volatile, that it is simply difficult for analysts to accurately forecast its earnings. In the absence of any private information, banks will also view the firm as very risky. In this case, one could observe that banks charge firms high interest rates when the absolute value of analysts' forecast errors are high, despite the possibility that banks may have no relative information advantage over analysts at all. In other words, although I have controlled for many factors that are known to influence loan spreads, those controls are likely to be incomplete. A correlated omitted variable problem might still exist and cause a spurious association in the OLS regression.

To address this concern, I construct three additional control variables. The first variable is complexity (COMPLEX), measured as the mean absolute value of analyst forecast errors (actual EPS minus consensus EPS forecast) over the 4 fiscal quarters prior to the loan quarter, deflated by the absolute value of last quarter's consensus EPS forecast. This variable is expected to partly control for business and forecast complexity. In addition, to the extent that the incentives in place that cause analysts to bias their forecasts are stable over a short period of time, this variable may also control for analysts' systematic forecast bias. The second variable is earnings volatility (EARN_VOL), measured as the standard deviation of quarterly earnings before 
extraordinary items (item 8) over the 4 fiscal quarters prior to the loan quarter, scaled by the standard deviation of quarterly CFO (item 108) over the same window. ${ }^{6}$ The third variable is return volatility (RET_VOL), measured as the standard deviation of the monthly returns over the 12 months prior to the loan initiation month. I use these two variables to control for operational uncertainty, which may affect banks' perceived default risk as well as the unexpected earnings measure. To the extent that these controls are successful, the correlated omitted variable problem should be mitigated.

\subsection{Estimation Models}

To test the first hypothesis (H1), I estimate the following model:

$$
\begin{aligned}
& \text { AISD }=\alpha+\beta_{1} * \text { UE }+\beta_{2} * \text { FSIZE }+\beta_{3} * \text { MATURITY }+\beta_{4} * \text { SECURE }+\beta_{5} * \text { TAKEOVER } \\
& +\beta_{6} * \text { LEVERAGE }+\beta_{7} * \text { RATING }+\beta_{8} * \text { D_NR }+\beta_{9} * \text { ASSETS }+\beta_{10} * \text { TobinQ } \\
& +\beta_{11} * \text { LAGRET }+\beta_{12} * \text { COMPLEX }+\beta_{13} * \text { EARN_VOL }+\beta_{14} * \text { RET_VOL }+\varepsilon
\end{aligned}
$$

H1 predicts that $\beta_{1}<0$. The greater the relative information advantage, the more negative the $\beta_{1}$. In addition, if $\beta_{1}$ really captures banks' superior information, I expect to see that it varies cross-sectionally and over time in predictable ways. In other words, the absolute magnitude of $\beta_{1}$ will be greater (lower) in cases when banks' relative information advantage is expected to be larger (smaller). To perform these contingency analyses, I construct dichotomous variables for negative unexpected earnings (NUE), secured loans (SECURE), high analyst following (D_AF), and post-Reg FD period

\footnotetext{
${ }^{6}$ The results are qualitatively the same if using the standard deviation of earnings alone or the standard deviation of CFO alone.
} 
(Aft_RFD) to test hypothesis 2, 3, 4 and 6 respectively. To test hypothesis 5, I calculate signed abnormal accruals (SAA) using the modified Jones model:

$$
\mathrm{TA}=\mathrm{k}_{1}+\mathrm{k}_{2} * \Delta \mathrm{REV}+\mathrm{k}_{3} * \mathrm{PPE}+\varepsilon
$$

where TA is the total accruals for firm $\mathrm{i}$ in year $\mathrm{t}$, calculated as the earnings before extraordinary items (item 123) minus the operating cash flows (item 308). $\triangle \mathrm{REV}$ is the annual change in revenues (item 12), and PPE is the gross value of property, plant and equipment (item 7). Regression (*) is estimated for each of the 48 Fama and French (1997) industry groups for each year and the coefficient estimates are used to estimate the firm-specific normal accruals (NA) for my sample firms as follows:

$$
N A=\hat{k}_{1}+\hat{k}_{2}(\Delta R E V-\Delta A R)+\hat{k}_{3} P P E+\varepsilon
$$

where $\Delta \mathrm{AR}$ is the annual change in account receivables. To account for possible heteroskadasticity, all variables in $(*)$ and $(* *)$, including intercepts, are scaled by lagged total assets (item 6). SAA is calculated as the difference between the deflated total accruals and the fitted normal accruals. Pos_AA (Neg_AA) takes value 1 if SAA $>0(<0)$, and 0 otherwise. I match each firm-quarter with Pos_AA (Neg_AA) of the past year.

To test the cross-sectional predictions (H2-H5), I estimate the following model: ${ }^{7}$

$$
\begin{aligned}
& \mathrm{AISD}=\alpha+\beta_{1} * \mathrm{UE}+\beta_{2} * \mathrm{NUE}+\beta_{3} * \mathrm{UE} * \mathrm{NUE}+\beta_{4} * \mathrm{SECURE}+\beta_{5} * \mathrm{UE} * \mathrm{SECURE}+ \\
& \beta_{6} * \mathrm{D} \_\mathrm{AF}+\beta_{7} * \mathrm{UE} * \mathrm{D} \_\mathrm{AF}+\beta_{8} * \text { Pos_AA }+\beta_{9} * \mathrm{UE} * \text { Pos_AA }+\beta_{10} * \mathrm{Neg} \_\mathrm{AA}+\beta_{11} * \mathrm{UE} \\
& * \text { Neg_AA }+ \text { Controls }+\varepsilon
\end{aligned}
$$

To test the time-series prediction (H6), I estimate the following model:

$$
\mathrm{AISD}=\alpha+\beta_{1} * \mathrm{UE}+\beta_{2} * \mathrm{Aft} \_\mathrm{FD}+\beta_{3} * \mathrm{UE} * \mathrm{Aft} \_\mathrm{FD}+\text { Controls }+\varepsilon
$$

\footnotetext{
${ }^{7}$ The results are qualitatively the same if estimating each interaction in Model (2) in a separate regression.
} 
"Controls" denote all the independent variables in regression (1) except UE. I predicted that $\beta_{3}<0, \beta_{5}>0, \beta_{7}>0$ and $\beta_{9}<0$ in Model (2) and $\beta_{2}<0$ in Model (3).

Since the above models are estimated using pooled panel data, I include year and industry fixed effects in all regressions. ${ }^{8}$ Furthermore, I compute t-statistics based on robust standard errors clustered by firm. The estimated variance-covariance matrix is a modified Huber/White/sandwich estimate of variance, which is robust to heteroskedasticity and has been adjusted to account for within-cluster correlation across residuals. Petersen (2005) demonstrates that when the residuals of a given firm are correlated across years, robust standard errors clustered by firm are unbiased and produce correctly sized confidence intervals.

\subsection{The Time Line}

Figure 4.1 illustrates the sequence of events: (1) banks set loan spreads for loan facilities with active dates in fiscal quarter $t$ based on all available public and private information; (2) by construction, all analysts' most recent earnings forecasts for quarter t are issued after the facility active date, up to the earnings announcement date; (3) quarter t earnings are announced, usually about 40 days after the end of the fiscal quarter; (4) quarter $\mathrm{t}$ bank loan agreements are filed with the SEC as material contracts in 10Ks or 10Qs, normally several months after the earnings announcement date. ${ }^{9}$

\footnotetext{
${ }^{8}$ The results are robust to including the fixed effects of the five largest lead banks in terms of market share, Bank of America, Bank One, Chase, Citibank and Wachovia.

${ }^{9}$ It is possible that some loan contracts are filed in $8 \mathrm{Ks}$ at the end of my sample period. But I haven't found a single case of such $8 \mathrm{~K}$ filings after hand collecting and checking over 200 loan contracts.
} 
Analyst Forecasts (2)

\begin{tabular}{|c|c|c|c|}
\hline $\begin{array}{c}\text { Facility } \\
\text { Active Date } \\
\text { (1) }\end{array}$ & $\begin{array}{c}\text { Fiscal } \\
\text { Quarter End }\end{array}$ & $\begin{array}{c}\text { Earnings } \\
\text { Announcement Date }\end{array}$ & $\begin{array}{l}\text { Loan Contract } \\
\text { Filing Date } \\
\text { (4) }\end{array}$ \\
\hline
\end{tabular}

\section{Figure 4.1: The Time Line}

All control variables capturing firm-specific characteristics (such as total assets and leverage) are measured in the fiscal quarter ending at least two months before the facility active dates to ensure that the related accounting information is available when banks set loan spreads. In contrast, unexpected earnings are calculated for the fiscal quarter in which the loan facility is initiated, subject to the restriction that all analysts' forecasts are issued after the facility active date.

The time line above suggests that analysts normally do not observe bank loan terms until well after the earnings announcement date, when loan agreements are filed with the SEC as material contracts. To the extent that some firms may voluntarily disclose loan terms before the earnings announcement date and that analysts are able to update their earnings forecasts accordingly, it will bias against rejecting the null. 


\section{CHAPTER 5}

\section{RESULTS}

\subsection{Descriptive Statistics}

Table 5.1 presents descriptive statistics for the final sample of the 5,859 observations that are used in the main analyses. To assess the extent to which the sample characteristics are comparable to those of the population of interest, Table 5.1 also provides descriptive statistics for two matched unrestricted samples. Since all variables in Panel A are obtained from the Dealscan database, a natural benchmark for comparison is the original Dealscan sample, which includes 20,153 bank loan facilities borrowed by publicly-traded US corporations from January 1987 to June 2005. And because all variables in Panel B are constructed using financial data from COMPUSTAT and $\mathrm{I} / \mathrm{B} / \mathrm{E} / \mathrm{S}$, the unrestricted sample in panel B (COMPUSTAT \& IBES sample) is the 232,479 firm-quarter observations that have financial data on both COMPUSTAT and $\mathrm{I} / \mathrm{B} / \mathrm{E} / \mathrm{S}$ during the same period.

Panel A compares loan characteristics and credit rating measures. The mean (median) AISD for the final sample is 137 basis points (100 basis points) over LIBOR. Both are significantly lower than their counterparts in the original Dealscan sample (198 and 175 basis points respectively). Loans in the final sample are on average significantly 
larger ( $\$ 470$ million versus $\$ 296$ million) and less likely to require collaterals (35.3\% versus $50.6 \%$ ), although there is no difference in the median loan maturity (36 months). Finally, borrowers in the final sample on average have slightly better S\&P senior debt rating $(9.56 \text { versus } 10.45)^{10}$, and they are significantly more likely to have a credit rating than firms in the original Dealscan sample ( $94.4 \%$ versus $50.2 \%$ ).

Panel B compares firm characteristics. The reported numbers for UE are after winsorization. The mean UE for the final sample is -0.027 , comparable to -0.033 for the unrestricted sample. The median UE for the final sample is significantly larger than that of the unrestricted sample (0.024 versus 0.005$)$, suggesting that my sample has higher percentage of firms with positive UE. This sample selection bias is likely to work against rejecting the null, but further understanding of the causes and consequences of the bias may be needed to draw cleaner inferences. Compared to average firms covered by both COMPUSTAT and I/B/E/S, firms in the final sample are on average significantly larger in terms of total assets ( $\$ 5,243$ million versus $\$ 4,632$ million) and more profitable in terms of ROA (5.2\% versus $4.1 \%)$ and prior stock performance (19\% versus $15 \%)$. They also feature a lower percentage of negative earnings surprises (28\% versus $37 \%$ ), on average more analyst following (7.6 versus 4.4), and significantly lower forecast complexity (0.37 versus 0.64$)$, earnings volatility (0.469 versus 0.881$)$ and return volatility $(0.126$ versus 0.144$)$. Overall, it seems that banks are less likely to have an informational advantage over analysts for my sample firms as compared to the firms in unrestricted samples, which creates another bias against rejecting the null.

\footnotetext{
${ }^{10}$ By construction, lower number indicates better credit rating. For example, 1 denotes "AAA", 9 denotes "BBB", 10 denotes "BBB-", and 11 denotes "BB+".
} 
Panel A: Loan Characteristics and Credit Rating

\begin{tabular}{|c|c|c|c|c|c|c|c|}
\hline \multirow{2}{*}{ Variable } & \multicolumn{5}{|c|}{ Final Sample } & \multicolumn{2}{|c|}{ Original Dealscan Sample } \\
\hline & Mean & Median & STD & Q1 & Q3 & Mean & Median \\
\hline AISD & 137 & 100 & 113 & 50 & 200 & 198 & 175 \\
\hline FSIZE & 470 & 200 & 840 & 75 & 500 & 296 & 92 \\
\hline MATURITY & 36 & 36 & 24 & 12 & 60 & 40.6 & 36 \\
\hline SECURE & 0.353 & $\mathbf{0}$ & 0.48 & 0 & 1 & 0.506 & 1 \\
\hline RATING & 9.56 & 9 & 3.34 & 7 & 12 & 10.45 & 10 \\
\hline D_NR & 0.056 & 0 & 0.23 & 0 & 0 & 0.498 & 0 \\
\hline $\mathrm{N}$ & \multicolumn{5}{|c|}{5,859} & 20,15 & \\
\hline
\end{tabular}

Panel B: Borrower Characteristics

\begin{tabular}{|c|c|c|c|c|c|c|c|}
\hline \multirow{2}{*}{ Variable } & \multicolumn{5}{|c|}{ Final Sample } & \multicolumn{2}{|c|}{ COMPUSTAT \& IBES } \\
\hline & Mean & Median & STD & Q1 & Q3 & Mean & Median \\
\hline UE & -0.027 & 0.024 & 0.91 & -0.02 & 0.11 & -0.033 & 0.005 \\
\hline NUE & 0.279 & 0 & 0.45 & 0 & 1 & 0.371 & 0 \\
\hline $\begin{array}{l}\text { Analyst } \\
\text { Following }\end{array}$ & 7.63 & 6 & 5.87 & 3 & 10 & 4.45 & 3 \\
\hline Aft_FD & 0.374 & 0 & 0.48 & 0 & 1 & 0.224 & 0 \\
\hline LEVERAGE & 0.241 & 0.225 & 0.18 & 0.10 & 0.35 & 0.185 & 0.135 \\
\hline ASSETS & 5243 & 1029 & 21900 & 334 & 3742 & 4632 & 447 \\
\hline TobinQ & 1.849 & 1.489 & 1.295 & 1.17 & 2.08 & 2.137 & 1.41 \\
\hline LAGRET & 0.19 & 0.10 & 0.67 & -0.16 & 0.39 & 0.15 & 0.04 \\
\hline ROA & 0.052 & 0.051 & 0.03 & 0.03 & 0.06 & 0.041 & 0.045 \\
\hline COMPLEX & 0.372 & 0.099 & 0.93 & 0.04 & 0.26 & 0.636 & 0.143 \\
\hline EARN_VOL & 0.469 & 0.178 & 0.8 & 0.09 & 0.39 & 0.881 & 0.265 \\
\hline RET_VOL & 0.126 & 0.112 & 0.07 & 0.08 & 0.15 & 0.144 & 0.115 \\
\hline $\mathrm{N}$ & \multicolumn{5}{|c|}{5,859} & \multicolumn{2}{|c|}{232,479} \\
\hline
\end{tabular}

Table 5.1: Descriptive Statistics

(Continued)

Notes: STD denotes standard deviation. Q1 (Q3) denotes the $25^{\text {th }}\left(75^{\text {th }}\right)$ percentile. The unit for FSIZE and ASSETS is \$million. The unit for MATURITY is month. Original Dealscan Sample includes all 20,153 loan facilities borrowed by publicly-traded U.S. corporations from January 1987 to June 2005. Compustat \& IBES denotes 232,479 firm-quarters with data on both COMPUSTATand I/B/E/S during the same period. ROA is measured as earnings (item 8) divided by total assets (item 44). Analyst Following is the number of analysts issuing EPS forecasts for the firm-quarter. See Appendix for other variable definitions. The bolded numbers are statistically different from their counterparts of the unrestricted sample according to t-tests for means and Wilcoxon tests for medians. 
Table 5.1 (continued)

Panel C: Distribution by Year

\begin{tabular}{cccc}
\hline \hline Year & Number of Observations & AISD & Analyst Following \\
\hline 1988 & 5 & 136 & 6 \\
1989 & 52 & 145 & 6 \\
1990 & 116 & 120 & 6 \\
1991 & 104 & 167 & 6 \\
1992 & 140 & 141 & 7 \\
1993 & 143 & 126 & 6 \\
1994 & 254 & 103 & 8 \\
1995 & 242 & 104 & 7 \\
1996 & 280 & 110 & 7 \\
1997 & 335 & 95 & 7 \\
1998 & 278 & 116 & 7 \\
1999 & 305 & 132 & 7 \\
2000 & 366 & 127 & 9 \\
2001 & 397 & 131 & 10 \\
2002 & 354 & 144 & 9 \\
2003 & 467 & 171 & 9 \\
2004 & 342 & 157 & 9 \\
\hline \hline
\end{tabular}

Panel D: Distribution by Industry

\begin{tabular}{clcc}
\hline 2-digit SIC Code & Industry & \# of Observations & Percentage \\
\hline 13 & Oil and Gas & 351 & 8.4 \\
20 & Food & 170 & 4.1 \\
26 & Paper & 125 & 3.0 \\
28 & Chemicals & 307 & 7.3 \\
33 & Primary Metal & 107 & 2.6 \\
35 & Machinery and Computer & 271 & 6.5 \\
36 & Electrical Equipment & 202 & 4.8 \\
37 & Transportation Equipment & 156 & 3.7 \\
38 & Lab and Medical Instruments & 161 & 3.9 \\
50 & Wholesale Trade & 159 & 3.8 \\
53 & General Merchandise Store & 123 & 2.9 \\
59 & Miscellaneous Retail & 114 & 2.7 \\
73 & Business Services & 192 & 4.6 \\
80 & Health Services & 133 & 3.2 \\
\hline \hline
\end{tabular}

Notes: Panel C and panel D show descriptive statistics for the final sample. For parsimony, industries with less than 100 observations in the final sample are not tabulated in Panel D. 
One confounding issue is that analysts are less likely to provide updates on a timely basis for poorly performing firms, while banks tend to more actively scrutinize borrowers when the borrowers' performance deteriorates. If poorly performing firms are heavily represented in my sample, then one would expect to derive similar results in the absence of banks' superior information. Table 5.1 partly refutes this alternative explanation. The borrowers in my final sample are on average larger, more profitable, and have better credit ratings than the average firm in the population of interest. Banks recognize that and offer them larger loans at significantly lower interest rates. In addition, I have controlled for various performance measures such as lagged stock return and credit rating in the multivariate regression analyses to mitigate this concern.

Panel C of Table 5.1 illustrates the distribution of the final sample by year. Over time, more observations enter the sample. On average there is greater analyst following after Reg FD than before Reg FD. No monotonic patterns are observed for AISD over time. Panel D shows that the sample is evenly distributed across industries. No industry consists of more than $10 \%$ of the final sample.

The Pearson correlation coefficients between selected variables are tabulated in Table 5.2. At the univariate level, loan spreads tend to be larger for secured loans, smaller loans, or borrowers with more negative unexpected earnings. The control variables for forecasting complexity and operational uncertainty, COMPLEX, EARN_VOL, and RET_VOL, are positively correlated with loan spreads, as predicted. Consistent with prior literature, larger borrowers or borrowers with lower leverage are associated with smaller loan spreads. 


\begin{tabular}{|c|c|c|c|c|c|c|c|c|c|c|}
\hline Variable & 1 & 2 & 3 & 4 & 5 & 6 & 7 & 8 & 9 & 10 \\
\hline 1.AISD & 1.00 & & & & & & & & & \\
\hline 2.UE & -0.11 & 1.00 & & & & & & & & \\
\hline 3.SECURE & 0.50 & -0.04 & 1.00 & & & & & & & \\
\hline 4.COMPLEX & 0.22 & -0.07 & 0.12 & 1.00 & & & & & & \\
\hline 5.FSIZE & -0.40 & 0.08 & -0.25 & -0.16 & 1.00 & & & & & \\
\hline 6.MATURITY & 0.02 & 0.02 & 0.15 & 0.02 & 0.04 & 1.00 & & & & \\
\hline 7.LEVERAGE & 0.11 & -0.02 & 0.06 & 0.07 & 0.22 & 0.12 & 1.00 & & & \\
\hline 8.ASSETS & -0.44 & 0.07 & -0.39 & -0.15 & 0.77 & -0.12 & 0.20 & 1.00 & & \\
\hline 9.TobinQ & -0.09 & 0.04 & -0.04 & -0.11 & -0.08 & -0.08 & 0.20 & -0.24 & 1.00 & \\
\hline 10.EARN_VOL & 0.23 & -0.05 & 0.15 & 0.20 & -0.12 & -0.02 & 0.00 & -0.10 & 0.03 & 1.00 \\
\hline 11.RET_VOL & 0.43 & -0.05 & 0.30 & 0.15 & -0.33 & -0.05 & -0.08 & -0.34 & 0.11 & 0.27 \\
\hline
\end{tabular}

\section{Table 5.2: Correlation Analysis}

Notes: Pearson correlations are reported. Bolded numbers are significant at the $1 \%$ level (two-tailed). To evaluate the concern of multi-collinearity, VIFs are checked for all independent variables. The VIFs are all less than 5, far below 10 . The results are robust to leaving out each of the highly correlated variables, and to the standard procedure of centering highly correlated variables at zero to mitigate the multicollinearity problem. 
Not surprisingly, some independent variables are highly correlated. For example, big firms tend to borrow larger loan facilities, and borrowers with high return volatility are more likely to get secured loans. It is therefore important to control for firm size, return volatility, and other measures to help mitigate the correlated omitted variable problem that may interfere with the interpretation of results.

\subsection{Multivariate Analyses}

Table 5.3, 5.4 and 5.5 present the main results. Table 5.3 investigates the impact of unexpected earnings on bank loan spreads in a multivariate regression, controlling for a variety of loan and firm-specific measures that proxy for default risk or earnings forecast complexity. To mitigate the influence of outliers, all independent variables are winsorized at the top and bottom $1 \%$.

The coefficient on UE is negative and significant at the $1 \%$ level, consistent with the prediction of H1. This result indicates that banks exploit their superior information about borrowers' future earnings in assessing potential loans and charge higher interest rates on firms with poor prospects of future earnings.

Besides the statistical significance, it is also helpful to discuss the economic significance of this result. Since the standard deviation of UE is 0.91 for the whole sample, one standard deviation decrease in UE is associated with an average increase of six basis points in loan spreads. However, because banks care more about downside risk, it might be misleading to mingle the positive and negative UE together in assessing the economic magnitude. Hence, I also estimate the same regression (untabulated) on a subsample of observations with negative UE only, where UE has a standard deviation of 1.3. 


\begin{tabular}{|c|c|c|c|}
\hline Variable & Predicted Sign & Coefficient & T-statistic \\
\hline UE & - & -6.641 & $(-3.07)^{* * *}$ \\
\hline FSIZE & $?$ & -13.292 & $(-7.13)^{* * *}$ \\
\hline MATURITY & $?$ & -2.107 & $(-1.15)$ \\
\hline SECURE & $?$ & 61.371 & $(18.66)^{* * *}$ \\
\hline TAKEOVER & + & 25.639 & $(6.34)^{* * *}$ \\
\hline LEVERAGE & + & 77.150 & $(8.97)^{* * *}$ \\
\hline RATING & + & 1.871 & $(5.90)^{* * *}$ \\
\hline D_NR & + & 24.902 & $(2.12)^{* *}$ \\
\hline ASSETS & - & -13.151 & $(-7.03)^{* * *}$ \\
\hline TobinQ & $?$ & -6.591 & $(-5.57)^{* * *}$ \\
\hline LAGRET & $?$ & -2.603 & $(-1.37)$ \\
\hline COMPLEX & + & 11.390 & $(6.67)^{* * *}$ \\
\hline EARN_VOL & + & 8.490 & $(4.39)^{* * *}$ \\
\hline RET_VOL & + & 384.992 & $(11.95)^{* * *}$ \\
\hline Year Fixed Effects & & YES & \\
\hline $\begin{array}{l}\text { Industry Fixed } \\
\text { Effects }\end{array}$ & & YES & \\
\hline $\mathrm{N}$ & & 5,859 & \\
\hline Adjusted $\mathrm{R}^{2}$ & & 0.50 & \\
\hline
\end{tabular}

Table 5.3: Multivariate Regression of Loan Spreads on Unexpected Earnings

Notes: The dependent variable is AISD. T-statistics are computed based on robust standard errors clustered at the firm level. See Appendix for variable definitions.

$* * *, * *, *$ denote significance at the $1 \%, 5 \%$, and $10 \%$ level respectively based on one-tailed tests for coefficients with clear predicted signs, and two-tailed tests for those without. 
As expected, the coefficient on UE is -12 , much bigger than the -6.6 reported in Table 5.3. This result suggests that one standard deviation decrease in negative UE is associated with an average increase of 15.6 basis points in loan spreads. Since several aspects of the empirical design bias against rejecting the null, this number may approximate the lower bound of the economic magnitude. The actual magnitude is likely to be much larger. In fact, after correcting for possible measurement errors in UE using an instrumental variable estimation, the coefficient on predicted UE becomes -20.3 for the whole sample (see Table 6.1). So on average a decrease of one standard deviation in UE is associated with an increase of 18.5 basis points in loan spread, which is about $20 \%$ of the median loan spread in the sample and can be translated into one million dollar increase in banks' interest income for an average loan facility borrowed by my sample firms.

Consistent with the findings in Strahan (1999), smaller loans, loans that are secured and loans with shorter maturity are associated with higher interest rates, even after controlling for publicly available measures of default risk.

The coefficients on most borrower-specific control variables have expected signs and are significantly associated with loan spreads. The results are robust to adding other firm-specific determinants of default risk in the model, such as interest coverage, current ratio, Altman's Z-score, Ohlson's O-score, stock price and ROA. The adjusted $\mathrm{R}^{2}$ of $50 \%$ is also comparable to $46 \%$ in Sufi (2007) and 47.4\% in Asquith et al. (2005).

\subsection{Cross-sectional Variations}

Table 5.4 examines whether banks' relative information advantage over analysts varies cross-sectionally in predictable ways and whether my empirical design is powerful 
enough to capture the changes in the relative information advantage. The regression results imply that banks seem to have correctly anticipated the signs of future earnings shocks that were unexpected by analysts, and have reflected them in loan spreads asymmetrically. The coefficient on the interaction between UE and NUE is significantly negative, suggesting that negative unexpected earnings news is assigned higher weight in determining loan spreads than positive unexpected earnings news. This result provides support for $\mathrm{H} 2$.

Consistent with $\mathrm{H} 3$, the coefficient on the interaction between SECURE and UE is significantly positive, indicating that loan spreads are less sensitive to unexpected earnings for secured loans than non-secured ones. ${ }^{11}$

To test H4, I construct a dummy variable (D_AF) that equals 1 when the number of analysts covering the firm is greater than 4, approximately the average number of the analyst following for the merged population of Compustat and I/B/E/S, and 0 otherwise. I then use D_AF to proxy for high analyst following. Consistent with H4, the coefficient on the interaction of D_AF with UE is significantly positive, implying that banks' relative information advantage is mitigated for firms with high analyst following.

Consistent with H5, the coefficient on the interaction of the income-increasing abnormal accruals (Pos_AA) with UE is significantly negative, suggesting that banks have greater relative information advantage about those borrowers that have incomeincreasing accruals in the previous year.

\footnotetext{
${ }^{11}$ One concern is that loan spreads and the requirement for collateral may be simultaneously determined. I also run a two-stage least-squares estimation and substitute the predicted value from the first stage for SECURE. The results are weaker but remain qualitatively similar after partially adjusting for endogeneity.
} 


\begin{tabular}{|c|c|c|c|}
\hline Variable & Predicted Sign & Coefficient & T-statistic \\
\hline UE & - & -0.533 & $(-0.11)$ \\
\hline NUE & + & 5.894 & $(2.02)^{* *}$ \\
\hline $\mathrm{UE} * \mathrm{NUE}$ & - & -11.754 & $(-2.51)^{* * *}$ \\
\hline D_AF & - & -15.259 & $(-4.66)^{* * *}$ \\
\hline $\mathrm{UE} * \mathrm{D} \_\mathrm{AF}$ & + & 8.946 & $(1.96)^{* *}$ \\
\hline SECURE & $?$ & 60.356 & $(17.13)^{* * *}$ \\
\hline UE * SECURE & + & 10.068 & $(2.57)^{* * *}$ \\
\hline Pos_AA & + & 11.859 & $(0.40)$ \\
\hline UE $*$ Pos_AA & - & -77.670 & $(-3.21)^{* * *}$ \\
\hline Neg_AA & $?$ & -45.891 & $(-1.74)^{*}$ \\
\hline UE $*$ Neg_AA & $?$ & -13.411 & $(-0.54)$ \\
\hline Controls & & YES & \\
\hline Year Fixed Effects & & YES & \\
\hline Industry Fixed Effects & & YES & \\
\hline $\mathrm{N}$ & & 5,097 & \\
\hline Adjusted $\mathrm{R}^{2}$ & & 0.51 & \\
\hline
\end{tabular}

\section{Table 5.4: Cross-sectional Analyses of Banks' Relative Information Advantage}

Notes: The dependent variable is AISD. T-statistics are computed based on robust standard errors clustered at the firm level. Control variables are the same as in Table 5.3. See Appendix for variable definitions.

$* * *, * *, *$ denote significance at the $1 \%, 5 \%$, and $10 \%$ level respectively based on one-tailed tests for coefficients with clear predicted signs, and two-tailed tests for those without. 


\subsection{Changes Before and After Reg FD}

Effective October $23^{\text {rd }}, 2000$, Reg FD prohibits private communications between managers and analysts. To the extent that before Reg FD analysts are able to cultivate management access to get more accurate signals about earnings, and to the extent that after Reg FD firms may withhold proprietary information or bad news that is earningsrelevant, Reg FD triggers a structural change that may have consequences on the information environment. Previous empirical studies have produced mixed findings (Heflin, Subramanyam and Zhang, 2003; Bailey, Li, Mao, and Zhong, 2003; Mohanram and Sunder, 2006), partly because there are significant macro-environment changes during the same period, and it is difficult to disentangle the Reg FD treatment effect from simple before-and-after comparisons. ${ }^{12}$

Instead of comparing analyst forecast accuracy before and after Reg FD, Table 5.5 exploits the fact that if banks' private signals about future earnings become more precise, unexpected earnings will be more strongly associated with loan spreads. In Table 5.5, the interaction of Aft_RFD dummy with UE is negative and statistically significant $(p$-value $=0.026),{ }^{13}$ suggesting that banks have larger relative information advantage over analysts after Reg FD than before Reg FD.

\footnotetext{
${ }^{12}$ One notable exception is Jorion, Liu and Shi (2005), who exploit the fact that credit rating agencies are exempted from Reg FD and find that stock price responses to credit rating changes are greater after Reg FD.

13 The results are qualitatively the same if I include analyst following and the interaction of UE with analyst following in the regression to control for the changes in analyst coverage around Reg FD. The results are also robust to estimating Reg FD effects jointly with other interaction terms in Table 5.4.
} 


\begin{tabular}{|c|c|c|c|}
\hline Variable & Predicted Sign & Coefficient & T-statistic \\
\hline UE & - & -1.611 & $(-2.86)^{* * *}$ \\
\hline Aft_RFD & $?$ & 4.767 & $(0.56)$ \\
\hline UE $*$ Aft_RFD & - & -2.880 & $(-1.94)^{* *}$ \\
\hline FSIZE & $?$ & -12.574 & $(-6.22) * * *$ \\
\hline MATURITY & $?$ & 1.586 & $(0.81)$ \\
\hline SECURE & ? & 60.36 & $(23.71)^{* * *}$ \\
\hline TAKEOVER & + & 32.224 & $(7.46)^{* * *}$ \\
\hline LEVERAGE & + & 91.240 & $(9.74)^{* * *}$ \\
\hline RATING & + & 2.266 & $(6.68)^{* * *}$ \\
\hline D_NR & + & 19.278 & $(1.58)$ \\
\hline ASSETS & - & -20.168 & $(-10.07)^{* * *}$ \\
\hline TobinQ & $?$ & -8.541 & $(-6.26)^{* * *}$ \\
\hline LAGRET & $?$ & -3.069 & $(-1.58)$ \\
\hline COMPLEX & + & 13.071 & $(6.80)^{* * *}$ \\
\hline EARN_VOL & + & 10.258 & $(5.27)^{* * *}$ \\
\hline RET_VOL & + & 462.855 & $(13.81)^{* * *}$ \\
\hline Year Fixed Effects & & YES & \\
\hline Industry Fixed Effects & & YES & \\
\hline $\mathrm{N}$ & & 5,859 & \\
\hline Adjusted $\mathrm{R}^{2}$ & & 0.50 & \\
\hline
\end{tabular}

\section{Table 5.5: Inter-temporal Analysis of Banks' Relative Information Advantage}

Notes: The dependent variable is AISD. T-statistics are computed based on robust standard errors clustered at the firm level. See Appendix for variable definitions.

$* * *, * *, *$ denote significance at the $1 \%, 5 \%$, and $10 \%$ level respectively based on one-tailed tests for coefficients with clear predicted signs, and two-tailed tests for those without. 
Because banks are exempted from Reg FD, this analysis essentially performs a “difference-in-differences" test to filter out the confounding macro-environment changes, which allows me to disentangle the treatment effect of Reg FD on the information environment. The result supports H6 and provides cleaner evidence that the information environment for equity analysts gets worse after the regulation.

One concern is that the results in Table 5.3 and 5.4 may be driven by the post-FD observations. As a robustness check, I also run all regressions in Table 5.3 and 5.4 using a sub-sample that contains only those bank loan facilities announced before June 2000, well in advance of the effective date of Reg FD. The results are qualitatively the same.

\subsection{Risk or Information?}

As discussed above, to guard against the possibility that UE could be capturing a correlated omitted default risk factor, I explicitly control for a number of measures of default risk used in prior literature, such as credit rating and leverage. I find UE continues to be a significant predictor of loan spreads with these controls.

Despite these efforts, it is impossible to completely control for correlated omitted risk factors. To further mitigate the concern of possible risk explanations, I repeat the analyses for subsequent quarters. If the results disappear for the later quarters when the relative information advantage diminishes (after earnings announcements and after firms' filing of material contracts with the SEC, analysts may infer part of the private information and update the forecasts), then it lends more support for the information story, since risk factors are not likely to change a lot within a couple of quarters. 
Quarter $\mathrm{t}+1$

\begin{tabular}{|c|c|c|c|c|c|}
\hline Variable & $\begin{array}{l}\text { Predicted } \\
\text { Sign }\end{array}$ & Coefficient & T-statistic & Coefficient & T-statistic \\
\hline UE_f & $?$ & -3.286 & $(-1.73)^{*}$ & -2.001 & $(-0.40)$ \\
\hline FSIZE & $?$ & -13.607 & $(-7.23)^{* * *}$ & -13.650 & $(-7.07) * * *$ \\
\hline MATURITY & $?$ & -0.100 & $(-0.05)$ & -0.238 & $(-0.12)$ \\
\hline SECURE & $?$ & 60.324 & $(18.44) * * *$ & 63.190 & $(18.61)^{* * *}$ \\
\hline TAKEOVER & + & 24.667 & $(6.55)^{* * *}$ & 24.658 & $(6.40)^{* * *}$ \\
\hline LEVERAGE & + & 78.936 & $(8.59) * * *$ & 80.717 & $(8.33)^{* * *}$ \\
\hline RATING & + & 1.915 & $(5.76) * * *$ & 1.927 & $(5.52)^{* * *}$ \\
\hline D_NR & + & 31.042 & $(2.82) * * *$ & 33.587 & $(3.02)^{* * *}$ \\
\hline ASSETS & - & -12.420 & $(-6.67)^{* * *}$ & -11.813 & $(-6.20)^{* * *}$ \\
\hline TobinQ & $?$ & -6.253 & $(-5.30) * * *$ & -5.719 & $(-4.89)^{* * *}$ \\
\hline LAGRET & $?$ & -1.606 & $(-0.87)$ & -0.755 & $(-0.41)$ \\
\hline COMPLEX & + & 11.442 & $(6.50)^{* * *}$ & 10.738 & $(5.44)^{* * *}$ \\
\hline EARN_VOL & + & 7.465 & $(3.74) * * *$ & 6.780 & $(3.31)^{* * *}$ \\
\hline RET_VOL & + & 373.862 & $(11.25)^{* * *}$ & 371.174 & $(11.28)^{* * *}$ \\
\hline $\begin{array}{l}\text { Year } \\
\text { Fixed Effects } \\
\text { Industry } \\
\text { Fixed Effects }\end{array}$ & & YES & & YES & \\
\hline $\mathrm{N}$ & & 5,581 & & 5,228 & \\
\hline Adjusted $\mathrm{R}^{2}$ & & 0.51 & & 0.51 & \\
\hline
\end{tabular}

\section{Table 5.6: Multivariate Regression of Loan Spreads on Unexpected Earnings One Quarter and Two Quarters Forward}

Notes: The dependent variable is AISD. UE_f denotes unexpected earnings measured at quarter $t+1$ and quarter $t+2$ earnings announcement date respectively. See Appendix for other variable definitions. T-statistics are computed based on robust standard errors clustered at the firm level.

$* * *, * *, *$ denote significance at the $1 \%, 5 \%$, and $10 \%$ level respectively based on one-tailed tests for coefficients with clear predicted signs, and two-tailed tests for those without. 
In Table 5.6 column 1, I repeat the same analysis as Table 5.3 except that quarter $t+1$ unexpected earnings (UE_f) are used instead of quarter $t$ unexpected earnings (UE). Specifically, for each firm, UE_f is calculated as the difference between the actual EPS of quarter $\mathrm{t}+1$ and the consensus EPS forecast for quarter $\mathrm{t}+1$, deflated by the absolute value of this consensus EPS forecast. ${ }^{14}$ As we can see from the table, the results become weaker. The coefficient of UE_f is less than half the size of that of UE in Table 5.3 ( -3.29 versus -6.64$)$, and is only marginally significant.

In Table 5.6 column 2, quarter $\mathrm{t}+2$ unexpected earnings (similarly measured) are used in the multivariate regression. The coefficient of UE_f becomes even smaller and is statistically insignificant. This finding is consistent with the information story that as uncertainty gradually resolves and the private information at loan initiation eventually becomes public information, banks' relative information advantage also vanishes. If instead what this empirical design captures is a risk factor, it might be difficult to explain why this risk may diminish and disappear over a short period of time.

\footnotetext{
${ }^{14}$ For each analyst, only his or her most recent forecast of $\mathrm{EPS}_{\mathrm{t}+1}$ issued after the quarter $\mathrm{t}$ facility active date is taken. Consensus analyst forecast for quarter $t+1$ is measured as the median of these most recent forecasts.
} 


\section{CHAPTER 6}

\section{SENSITIVITY ANALYSES}

\subsection{Alternative Measures of Unexpected Earnings}

\subsubsection{Alternative deflators}

The underlying theoretical construct concerns banks' private information about borrowers' future earnings that is unexpected by the market. Because analysts' consensus earnings forecast is documented as a superior surrogate for market expectations (Brown and Rozeff, 1978; Givoly, 1982), I construct a proxy, UE, as the difference between the actual EPS and the consensus analyst forecast of EPS, deflated by the absolute value of the consensus analyst forecast of EPS. This measure is similar to the calculation of return and has an intuitive interpretation of percentage forecast error. One limitation is that the treatment of non-positive or close-to-zero consensus forecasts in the denominator may not be desirable. The standard solution in the literature is to use the beginning-of-thequarter stock price as the deflator and mitigate the small deflator problem by deleting observations with the stock price less than \$5. In Table 6.1 Model 1, I show that the results are robust to this alternative procedure of calculating UE. The problem with this price deflated measure, however, is that $\mathrm{P} / \mathrm{E}$ ratios may vary substantially across firms. More seriously, since price or $\mathrm{P} / \mathrm{E}$ ratio can be correlated with risk, it may confound or 
bias my results and make them hard to interpret (Durtschi and Easton, 2005). Alternatively, I use total assets per share as the deflator and the regression coefficient of the new UE measure remains statistically significant (beta $=-975.869$, $\mathrm{t}$-statistic $=$ $-2.61)$.

\subsubsection{Quarterly versus long-term earnings}

Banks typically care more about the long-run earnings prospects of the borrower than earnings for a single quarter. After all, the average loan maturity of my sample spans three years. It follows that running a horse-race of banks against analysts regarding quarterly earnings instead of long-term earnings may handicap banks and hence reduce the power of the test. To mitigate the concern, I examine whether the results are robust to using longer term analysts' forecasts to construct the unexpected earnings measure. Specifically, I re-run the main analyses using an unexpected earnings measure constructed based on analysts' annual earnings forecasts, with the restriction that only annual forecasts issued after the loan initiation and before the current quarter's earnings announcement date will be used. Table 6.1 Model 2 shows that the results are actually slightly stronger using this alternative measure. Ideally, I would like to match forecast horizon with loan maturity for each loan facility. ${ }^{15}$ However, data limitations make it less desirable. Compared with quarterly or annual analysts' forecasts, long-term analysts' forecasts are much less frequent, noisier and more susceptible to optimism (Bradshaw et al. 2006), which can lead to more serious errors-in-variable problems.

\footnotetext{
${ }^{15}$ The results remain for loans with maturity less than one year as well as those with maturity greater than one year or those with maturity greater than 3 years.
} 


\subsubsection{Instrumental variable estimation}

It is quite possible that UE may measure the theoretical construct with error. One example of potential measurement error is systematic analyst forecast bias, which could be correlated with risk factors such as prior performance and growth opportunities. Klein (1990) documents the fact that analysts issue more optimistic annual earnings forecasts for firms reporting recent losses than for firms reporting recent profits. Bradshaw et al. (2006) also find that optimism in analysts' forecasts is significantly positively associated with net external financing, a negative predictor of future profitability.

I implement several procedures to address this concern. First, to the extent that the systematic forecast bias is persistent over a short period of time, the control variable COMPLEX (measured as the average absolute analyst forecast error over the previous 4 quarters) should effectively control for the bias and mitigate the correlated omitted variable problem. Second, I have controlled for prior performance (LAGRET) and growth opportunities (TobinQ) in the regression. In an untabulated analysis, I also find the results are virtually the same if I use ROA (prior earnings level divided by total assets) instead of LAGRET as the control for prior performance. Third, I have demonstrated above that the association between unexpected earnings and loan spreads gradually disappear in two quarters after information gets revealed. For any risk story to hold, one has to explain why the correlated omitted risk factor will vanish over a short period of time. 
To further mitigate the potential errors-in-variable problem, I used cumulative abnormal returns over the 3-day window around the quarter $t$ earnings announcement date, $\operatorname{CAR}(-1,+1)$, as an instrument for the earnings unexpected by the market. It is well documented that abnormal returns around earnings announcement dates are correlated with unexpected earnings. In addition, in an efficient market it is reasonable to believe that abnormal return is not predictable, that is, $\operatorname{CAR}(-1,+1)$ is unlikely to be correlated with the measurement error in UE.

Two-stage-least-squares (2SLS) procedure is used for the instrumental variable estimation. In the first stage OLS regression, UE is projected on $\operatorname{CAR}(-1,+1)$ and other exogenous variables. In the second stage, AISD is regressed on the predicted value of UE from the first-stage estimation and other independent variables. As we can see from the second-stage OLS regression in Table 6.1 Model 3, the coefficient on the predicted UE has the same negative sign as predicted by Hypothesis 1 . Therefore, a one-tailed test is more appropriate here, which produces a $p$-value of 0.041 , suggesting that the coefficient is statistically significant at the $5 \%$ level and that the instrumental variable approach yields qualitatively similar results. It is worth noting that the coefficient of UE in the instrumental variable estimation is -20.33 , much larger than -6.64 in Table 5.3. This evidence suggests that the measurement error actually biases the coefficient toward zero, and that after correcting for the measurement error using the instrumental variable estimation, the economic magnitude of banks' relative information advantage is substantially higher. 


\begin{tabular}{|c|c|c|c|c|c|}
\hline \multirow[t]{2}{*}{ Variable } & \multirow[t]{2}{*}{$\begin{array}{l}\text { Predicted } \\
\text { Sign } \\
\end{array}$} & \multirow[t]{2}{*}{$\begin{array}{l}\text { Model 1: } \\
\text { UE } \\
\text { deflated by } \\
\text { Stock Price } \\
\end{array}$} & \multirow[t]{2}{*}{$\begin{array}{l}\text { Model 2: } \\
\text { UE based } \\
\text { on Annual } \\
\text { Forecasts }\end{array}$} & \multicolumn{2}{|c|}{$\begin{array}{c}\text { Model 3: } \\
\text { Instrumental } \\
\text { Variable Estimation }\end{array}$} \\
\hline & & & & First Stage & Second Stage \\
\hline UE_price & - & $\begin{array}{l}-1080.681 \\
(-3.91)^{* * *}\end{array}$ & & & \\
\hline UE_annual & - & & $\begin{array}{l}-6.896 \\
(-3.87)^{* * *}\end{array}$ & & \\
\hline $\operatorname{CAR}(-1,+1)$ & + & & & $\begin{array}{l}4.867 \\
(10.97)^{* * *}\end{array}$ & \\
\hline Predicted UE & - & & & & $\begin{array}{l}-20.327 \\
(-1.74)^{* *}\end{array}$ \\
\hline Controls & & YES & YES & YES & YES \\
\hline $\begin{array}{l}\text { Year } \\
\text { Fixed Effects } \\
\text { Industry }\end{array}$ & & YES & YES & YES & YES \\
\hline Fixed Effects & & YES & YES & YES & YES \\
\hline $\mathrm{N}$ & & 4,743 & 5,859 & 5,804 & 5,804 \\
\hline Adjusted $\mathrm{R}^{2}$ & & 0.52 & 0.52 & 0.04 & 0.51 \\
\hline
\end{tabular}

\section{Table 6.1: Alternative Measures of Unexpected Earnings}

Notes: The dependent variable is AISD for Model 1, Model 2 and the second stage of Model 3. For the first stage of Model 3, the dependent variable is UE.

UE_price is measured as the difference between the actual quarterly EPS and the consensus quarterly EPS forecast, deflated by the beginning-of-the-quarter price. UE_annual is calculated as the difference between the actual annual EPS and the consensus annual EPS forecast, deflated by the absolute value of the consensus annual EPS forecast. CAR $(-1,+1)$ is the cumulative abnormal return over the 3-day window around the earnings announcement date in quarter t. Predicted UE is the predicted value of UE in the first stage regression of the two-stage-least-squares (2SLS) estimation. Controls are the same control variables as those in Table 5.3. See Appendix for other variable definitions.

Reported in parentheses are t-statistics computed based on robust standard errors clustered at the firm level.

$* * *, * *, *$ denote significance at the $1 \%, 5 \%$, and $10 \%$ level respectively based on one-tailed tests for coefficients with clear predicted signs, and two-tailed tests for those without. 


\subsection{Tests of Alternative Interpretations}

\subsubsection{Mechanical association?}

One alternative interpretation of the results is that they are driven by a mechanical association. The fact that a firm obtains a bank loan implies that its interest expense for the current quarter is likely to increase, which may lead to negative unexpected earnings if the loan agreement is not voluntarily disclosed before the earnings announcement date. Holding facility size constant, the higher the interest rate, the larger the interest expense, hence the more negative the unexpected earnings. In order to test this alternative interpretation, I conduct the above analyses on a sub-sample where each borrower's current quarter interest expense actually decreases (44\% of the final sample). If the results are in fact driven by the mechanical association, then I expect to see no result for this sub-sample. Instead, Table 6.2 Model 1 reports that the coefficient on UE has the predicted sign and remains statistically significant. Alternatively, I construct a dummy variable of "interest expense decrease" and add interaction terms of the dummy variable with all independent variables in the regression. In an untabulated analysis, I find that the interactions are statistically insignificant for all variables of interest. Taken together, the evidence is inconsistent with the mechanical association argument.

\subsubsection{Knowledge of how the loan proceeds will be used?}

Banks have exclusive knowledge about the purpose of a specific loan facility before the loan agreement is announced, which may grant them an informational edge. For example, if the loan proceeds are used to fund a promising project, or to acquire a business with clear synergy value, banks will incorporate such information into loan 
spreads. Do banks have superior information simply because they are informed of how the loan proceeds will be used? I conduct two analyses to shed light on this alternative interpretation. First, a frequency plot of the loan purpose shows that the most frequent (about 30\%) use of the proceeds of my sample loans is coded "Corporate Purpose," which is defined as "catch-all purpose that can be used for various activities related to general operations, working capital and purchases" by Dealscan. It seems difficult to infer any future earnings-relevant information from knowing this vague description of loan purpose. Second, "Debt Repay" is the second most frequent loan purpose (22\%) in my sample. It is even less likely that banks can learn much about the borrower's future earnings by simply knowing that the money is being borrowed to pay down the existing debt. Therefore, if the knowledge of loan purpose is really what is driving the results, I expect that the results will disappear for a sub-sample of loans whose loan purpose is "Debt Repay". To the contrary, Table 6.2 Model 2 reports that the sensitivity of loan spreads to UE remains strong (beta $=-10.89$ ) and statistically significant. This result suggests that the knowledge of loan purpose is unlikely to be the source of the superior information that is driving the results.

\subsubsection{Access to monthly financial statements?}

Another alternative interpretation of the results is that banks do not engage in costly private information production at all and they have an information advantage simply because they can request the borrower to provide internally prepared monthly financial statements which are normally not accessible to equity analysts. If the exclusive access to monthly financial statements is the only source of banks' superior information, 
then we should observe no result for the loans initiated during the first month of the quarter (because the monthly reports haven't come out yet), and stronger results for the loans initiated during the second or the third month of the quarter (after the monthly reports become available to banks). The results in Table 6.2 Model 3 contradict these predictions. The main effect of UE is statistically significant, which suggests that banks incorporate future unexpected earnings into loan spreads even without access to monthly financial statements. The interaction effects between UE and both dummy variables, Month2 and Month3, are insignificant, which further indicates that having access to monthly financial reports is not what is driving the documented relative information advantage of banks.

\subsubsection{The impact of loan renewals?}

For loan renewals, banks may have gained substantial firm-specific knowledge by monitoring the existing loans and through repeated interactions with the borrower's management team. Hence ex post information advantage may play a dominant role for these loans rather than the ex ante information advantage that I try to capture. Are the results solely driven by loan renewals? To shed some light on this question, I partition the sample according to whether or not the loan facility belongs to the first deal for the borrower during the period of 1987-2005. In Table 6.2 Model 4, Loan_renew takes value

1 if the loan facility is initiated after another loan for the same borrower, and zero otherwise. The coefficient on UE remains statistically significant, which suggests that the results still hold for "new" loans within the sample period. The coefficient on the interaction of UE with Loan_renew has the predicted sign but is statistically insignificant. 


\begin{tabular}{|c|c|c|c|c|c|}
\hline Variable & $\begin{array}{l}\text { Predicted } \\
\text { Sign }\end{array}$ & $\begin{array}{l}\text { Model 1: } \\
\text { "Decreasing } \\
\text { Interest } \\
\text { Expense" } \\
\text { Sub-sample }\end{array}$ & $\begin{array}{l}\text { Model 2: } \\
\text { "Debt } \\
\text { Repay" } \\
\text { Sub- } \\
\text { sample }\end{array}$ & $\begin{array}{l}\text { Model 3: } \\
\text { Access to } \\
\text { Monthly } \\
\text { Reports }\end{array}$ & $\begin{array}{l}\text { Model 4: } \\
\text { The Impact } \\
\text { of Loan } \\
\text { Renewals }\end{array}$ \\
\hline UE & - & $\begin{array}{l}-8.778 \\
(-1.85)^{* *}\end{array}$ & $\begin{array}{l}-10.89 \\
(-2.18)^{* *}\end{array}$ & $\begin{array}{l}-7.685 \\
(-3.07)^{* * *}\end{array}$ & $\begin{array}{l}-5.837 \\
(-2.40)^{* * *}\end{array}$ \\
\hline Loan_renew & $?$ & & & & $\begin{array}{l}-1.420 \\
(-0.48)\end{array}$ \\
\hline UE*Loan_renew & - & & & & $\begin{array}{l}-0.978 \\
(-0.25)\end{array}$ \\
\hline Month2 & $?$ & & & $\begin{array}{l}6.088 \\
(1.37)\end{array}$ & \\
\hline UE*Month2 & - & & & $\begin{array}{l}1.326 \\
(0.28)\end{array}$ & \\
\hline Month3 & $?$ & & & $\begin{array}{l}0.574 \\
(0.21)\end{array}$ & \\
\hline UE*Month3 & - & & & $\begin{array}{l}4.253 \\
(0.94)\end{array}$ & \\
\hline Controls & & YES & YES & YES & YES \\
\hline $\begin{array}{l}\text { Year } \\
\text { Fixed Effects }\end{array}$ & & YES & YES & YES & YES \\
\hline $\begin{array}{l}\text { Industry } \\
\text { Fixed Effects }\end{array}$ & & YES & YES & YES & YES \\
\hline $\mathrm{N}$ & & 2,106 & 1,277 & 5,859 & 5,859 \\
\hline Adjusted $\mathrm{R}^{2}$ & & 0.52 & 0.48 & 0.53 & 0.53 \\
\hline
\end{tabular}

\section{Table 6.2: Tests of Alternative Interpretations}

Notes: The dependent variable is AISD. Loan_renew is a dichotomous variable that takes value 1 if the loan facility is initiated after another loan for the same borrower, and 0 otherwise. Month2 (Month3) is a dichotomous variable equal to 1 if the loan initiation date is in the second (third) month of fiscal quarter $t$, and 0 otherwise. Control variables are the same as those in Table 5.3.

Reported in parentheses are t-statistics computed based on robust standard errors clustered at the firm level.

$* * *, * *, *$ denote significance at the $1 \%, 5 \%$, and $10 \%$ level respectively based on one-tailed tests for coefficients with clear predicted signs, and two-tailed testsfor those without. 
To the extent that the first loan in the sample period is really a new loan for the borrower, this result implies that the sensitivity of loan spreads to UE does not differ between new loans and loan renewals, and that banks' superior information is not driven by loan renewals. However, it is quite possible that some borrowers may have loans from before 1987 that would not enter my sample. So this analysis is subject to the caveat that some loan renewals may be incorrectly coded as "new" loans. Cautions should be practiced in drawing inferences from this evidence.

\subsection{Further Evidence of Costly Private Information Production}

\subsection{1 "Investment Grade” versus "Speculative”}

The analyses in Table 5.4 provide some evidence that banks' relative information advantage varies cross-sectionally in predictable ways that are consistent with the changes in banks' economic incentives for private information production. For example, Table 5.4 reports that the sensitivity of loan spreads to UE is greater for firms with income-increasing abnormal accruals, consistent with the lead bank committing to retain large stakes and having incentives to scrutinize the borrower more carefully.

An alternative test is to partition the sample on more direct proxies of default risk,

for example, credit rating. Following the convention, I classify S\&P senior debt ratings of "BBB" and above as "Investment Grade" and those below "BBB" as "Speculative." Observations without a credit rating are deleted. According to Moody's investment service, the default probability over a four-year horizon for firms with "Aaa" rating is $0.002 \%$, which is negligible, while the default probability increases to an alarming $48 \%$ 
for those with "Caa" rating. Therefore, if banks do engage in costly private information production, they are likely to collect less private information for borrowers with "Investment Grade" ratings, but scrutinize those with "Speculative" ratings very carefully to price-protect themselves.

The results in Table 6.3 Model 1 provide some support for these predictions. The coefficient of UE is negative but not statistically different from zero, suggesting that banks have little superior information for borrowers with "Investment Grade" ratings. The coefficient on the interaction term of UE with Speculative has the predicted sign and is statistically significant, consistent with banks using credit rating as a screening device to help determine the intensity of private information production.

\subsubsection{The effect of performance pricing}

Performance pricing is a provision in bank debt contracts that establishes ex ante how changes in financial performance affect loan spreads (see Asquith et al., 2005). For example, if the borrower's credit quality as measured by the debt-to-EBITDA ratio deteriorates, performance pricing will allow banks to increase the loan spread to a predetermined amount without renegotiation.

I predict that banks are less likely to engage in private information production for loans with performance pricing provisions as compared to those without, because it is no longer critical to have a precise expectation of the borrower's earnings prospects once loan spreads are tied to its future financial performance. Consistent with the prediction, Table 6.3 Model 2 reports that the sensitivity of loan spreads to UE is significantly lower for loans with performance pricing provisions than those without. 


\begin{tabular}{|c|c|c|c|}
\hline Variable & $\begin{array}{l}\text { Predicted } \\
\text { Sign }\end{array}$ & $\begin{array}{l}\text { Model 1: } \\
\text { "Investment Grade" } \\
\text { versus "Speculative" }\end{array}$ & $\begin{array}{l}\text { Model 2: } \\
\text { The Effect of } \\
\text { Performance Pricing }\end{array}$ \\
\hline UE & - & $\begin{array}{l}-4.141 \\
(-1.16)\end{array}$ & $\begin{array}{l}-8.837 \\
(-3.02)^{* * * *}\end{array}$ \\
\hline SPECULATIVE & + & $\begin{array}{l}34.821 \\
(10.45)^{* * *}\end{array}$ & \\
\hline UE*SPECULATIVE & - & $\begin{array}{l}-5.506 \\
(-1.82)^{* *}\end{array}$ & \\
\hline Performance_pricing & - & & $\begin{array}{l}-27.803 \\
(-9.80) * * *\end{array}$ \\
\hline UE*Performance_pricing & + & & $\begin{array}{l}7.702 \\
(2.22)^{* * *}\end{array}$ \\
\hline Controls & & YES & YES \\
\hline Year Fixed Effects & & YES & YES \\
\hline Industry Fixed Effects & & YES & YES \\
\hline $\mathrm{N}$ & & 5,531 & 5,859 \\
\hline Adjusted $\mathrm{R}^{2}$ & & 0.51 & 0.54 \\
\hline
\end{tabular}

\section{Table 6.3: Further Evidence of Costly Private Information Production}

Notes: The dependent variable is AISD. SPECULATIVE is a dichotomous variable that takes value 1 if S\&P senior debt rating is below "BBB" and 0 if it is "BBB" and above. Performance_pricing is a dichotomous variable that takes value 1 if performance pricing provision is included in debt covenants, 0 otherwise. Control variables are the same as those in Table 5.3.

Reported in parentheses are t-statistics computed based on robust standard errors clustered at the firm level.

$* * *, * *, *$ denote significance at the $1 \%, 5 \%$, and $10 \%$ level respectively based on one-tailed tests for coefficients with clear predicted signs, and two-tailed tests for those without. 


\section{CHAPTER 7}

\section{LIMITATIONS}

\subsection{The Sources of the Superior Information}

The above analyses provide robust evidence consistent with banks having superior information to financial analysts regarding the borrower's future earnings. A natural follow-up question is: where does the superior information come from? It would be interesting to tailor the empirical design to specific sources of superior information, which might lead to refined predictions, more powerful tests and improved inferences. In this section, I discuss each potential source of superior information for future research.

\subsubsection{Banking relationship}

If the borrower has deposit or cash flow management services with the bank, it may grant the bank a unique "insider" view of the borrower's cash flows. In addition, relationship banking may help banks gain substantial firm-specific knowledge through repeated interactions with the borrower. A straightforward test, therefore, is to examine whether the sensitivity of loan spreads to UE is greater for borrowers with existing banking relationship as compared to those without. However, this test is subject to the caveat that one can only ascertain the lack of a banking relationship within the sample. Future studies might come up with a cleaner proxy for banking relationship. 


\subsubsection{Information spillovers from related industry or the supply chain}

Commercial banks are in the business of financing corporate projects. After evaluating and monitoring hundreds of borrowers in the same industry or those with related businesses, banks may have developed a degree of intuition or tacit knowledge about the future profitability of certain industry or certain projects. In addition, there may be information spillovers from the supply chain if banks have an existing relationship with a major supplier or customer of the borrower. Future studies may shed some light on this information source by exploring the effect of the lead bank's market share or business scope on its relative information advantage.

\subsubsection{Proprietary Information}

The voluntary disclosure literature cites proprietary cost as a major friction that prevents full disclosure (Dye, 1985). It is costly to disclose proprietary information to the public because it may trigger undesirable reactions from competitors. In contrast, firms may feel comfortable disclosing the proprietary information, especially good news, to banks as long as they sign confidentiality agreements. However, the cross-sectional analyses in Table 5.3 suggest that banks' relative information advantage is much greater for negative unexpected earnings than positive ones. It seems that banks hesitate to reduce loan spreads in response to prospective good news, but are ready to penalize the borrower with higher interest rates when they learn about potential bad news.

Moreover, prior to Regulation FD, managers could circumvent the proprietary cost via private communications with trusted analysts. For example, if managers privately observe a negative signal about future earnings, they can "whisper the numbers" to 
selected analysts to guide the earnings forecasts down so that they are able to meet or beat analysts' consensus forecast when the actual earnings are announced. Consistent with this argument, $\mathrm{Ke}$ and $\mathrm{Yu}(2005)$ document that most of the private information that analysts received from closed conference calls is bad news. To shed light on this source,

future studies need to find a setting where firms have incentives to disclose more bad news to banks than to their favorite equity analysts before Reg FD, as the results still hold for the pre-Reg FD sub-sample.

\subsection{Active Information Producer or Passive Information Receiver?}

At the financing decision stage, banks typically receive a variety of reports about the financial condition of the borrower, which may include financial statements, management forecasts, and detailed plans. The above analyses suggest that simple access to monthly financial statements, or mere knowledge of how the loan proceeds will be used, is not likely to be the main source of banks' superior information. But it is still possible that banks obtain the information advantage by simply requesting managers to provide detailed forecasts and estimates of the next five years' sales or cash flows. It is not feasible to exhaust the list of earnings relevant information that banks may receive.

On the other hand, in a competitive loan market, requiring large clients to provide additional private information is not without a cost, especially for my sample borrowers, which have average total assets of over $\$ 5$ billion and an average loan size of $\$ 470$ million. Depending on the cost-benefit tradeoffs, banks often conduct on-site inspection of the books and properties, have experienced staff analyze financial reports and 
management estimates, or assess the expected profitability and the risk of the underlying project based on their own detailed analyses of the industry, the supply chain and the past performance of similar projects.

It is quite possible that both better information access and private information production contribute to banks' relative information advantage. The current research design, however, cannot effectively distinguish which one of the two plays a more important role.

One promising direction toward addressing this issue is to compare banks with credit rating agencies. Credit rating agencies also focus on assessing default risk, and they have access to almost the same amount of borrower-specific information as banks. This may allow researchers to hold the information access dimension constant and draw cleaner inferences on the differences in information processing or information production capability.

Alternatively, one might compare bank financing with seasoned equity offering (SEO), where market forces may compel firms to disclose a similar amount of financial information to equity holders, and where analysts also have the greatest incentive to acquire and produce earnings-relevant information. 


\subsection{Thoughts on Alternative Ways to Triangulate the Research Question}

\subsubsection{Alternative model specifications}

$\operatorname{CAR}(-1,+1)$ could be used as a direct proxy for the underlying theoretical construct, that is, banks' private information about borrowers' earnings prospects that is unexpected by the market. One advantage is that the abnormal return measure does not require coverage by $\mathrm{I} / \mathrm{B} / \mathrm{E} / \mathrm{S}$, which will significantly increase the sample size. Compared with UE, the abnormal return measure is also less susceptible to measurement error. It would be interesting to repeat all the analyses replacing $\operatorname{UE}$ with $\operatorname{CAR}(-1,+1)$ and UE_f with the corresponding abnormal return measure, and check whether the results still hold.

Other independent variables could also be improved. For example, to construct COMPLEX, the same procedure in deriving UE is used to obtain the analyst forecast error for each of the 4 quarters prior to the loan initiation quarter, except that each forecast is required to be issued no earlier than 90 days before the earnings announcement date to avoid stale forecasts. Instead of choosing the most recent forecast for each analyst, however, an alternative approach is to pick the earliest forecast for each analyst, which may provide a better control for forecast complexity. It is also desirable to filter out the market-wide fluctuations contained in LAGRET by subtracting the corresponding cumulative market returns during the same period. Moreover, instead of analyst following, analyst dispersion is an alternative proxy for firm-specific public information environment, although it can be unreliable when analyst following is low. Finally, it may be helpful to control for analysts' consensus earnings forecast, in case that the expected component of earnings cannot be completely captured by other control variables. 


\subsubsection{Alternative cross-sectional analyses}

Once data on loan types are collected, it would be interesting to distinguish revolvers from term loans. A revolving loan is essentially a put option where the borrower obtains guaranteed access to a credit line at a fixed loan spread and has the flexibility to determine the timing and amount to draw down the credit line after the loan initiation. Since the borrower has an incentive to draw down additional amounts if its credit quality deteriorates, the agency cost of debt is likely to be higher for revolving loans than term loans, which in turn demands more careful evaluation. One approach is to partition the sample on loan types and examine whether the sensitivity of loan spreads to UE is stronger for revolving loans than term loans. The loan type data may also allow me to obtain a more refined sample by picking the revolving loan facility rather than randomly choosing one facility when there are multiple facilities in the same deal.

Another thought is to collect data on the percentage of the syndicated loan retained by the lead bank -- the variable used in Sufi (2007) -- and conduct the analysis based on this direct measure of banks' commitment to careful evaluation, instead of partitioning the sample on the indirect measure of income-increasing abnormal accruals.

Credit rating agencies provide valuable public information about the default risk, so borrowers with credit ratings likely have a different information environment from those without. Unfortunately, only $5.6 \%$ of the current sample firms are not rated. When CAR $(-1,+1)$ replaces UE in future analyses and the sample size gets larger, it would be interesting to examine whether banks have less information advantage for rated firms as compared to those that are not rated. 


\subsubsection{Simultaneous estimation of price and non-price terms}

Many loan contract terms are determined simultaneously. Relating price and nonprice terms using a single equation framework raises econometric issues because some of the independent variables are likely to be endogenous. As a result, the OLS estimates may be biased and inconsistent. The literature has developed two distinct approaches towards overcoming this endogeneity problem. One approach is to exclude endogenous non-price terms as independent variables, resulting in reduced form equations in which OLS estimates are unbiased (Guedes and Opler, 1996). In an untabluated analysis, I find that the results are robust to the reduced form estimation. The other approach is to jointly estimate price and non-price terms in a simultaneous equation framework, incorporating the interdependencies between contract terms (Dennis, Nandy and Sharpe, 2000). The challenge for this approach, however, is to find valid instruments in order to uniquely identify the simultaneous equation system.

\subsubsection{Alternative analyses exploiting the timing differences in information availability}

Once the loan contract filing dates are collected, it would be interesting to examine whether analysts update their earnings forecasts around borrowers' filing of loan agreements with SEC.

A small percentage of firms make voluntary announcements of bank loan agreements before filing with SEC. It would be interesting to look into this special subsample of borrowers, explore how their characteristics differ from the rest of the sample and investigate whether banks' relative information advantage becomes weaker or even disappears for these early announcers. 


\section{CHAPTER 8}

\section{CONCLUSIONS}

An important implication of contemporary theories of financial intermediation is that banks have superior information to external investors about borrowers' future prospects. Two strands of research have explored this superior information hypothesis and the findings are largely mixed. This paper exploits a new research design and detailed primary loan contract data to provide a more direct test of the hypothesis.

Focusing on a sample of publicly-traded US firms that have both bank debt and analyst following, I find evidence suggesting that banks set interest rates at the loan initiation as if they have anticipated the sign and magnitude of future earnings news, news that is unexpected by analysts. I also find that the sensitivity of loan spreads to unexpected earnings varies cross-sectionally and over time in predictable ways. The results are consistent with the superior information hypothesis, and are difficult to explain using a correlated omitted risk factor argument.

The findings of this paper have the following implications. First, the documented

differences between the information environments faced by banks and other investors may help us understand the different demands for financial reporting among external users. Second, the finding that banks' information advantage over analysts widened after 
Reg FD provides cleaner evidence that analysts' information environment has deteriorated since the regulation. Third, the evidence that banks still have an information advantage over analysts for publicly-traded U.S. borrowers implies that banks continue to play a critical role in mitigating informational asymmetries in the capital market. Finally, the results suggest that bank loan agreements contain valuable information about future earnings. To the extent that analysts can obtain and decipher the loan information on a timely basis, stock market efficiency may be improved. 


\section{APPENDIX}

\section{Variable Definitions}

\begin{tabular}{|c|c|}
\hline AISD & $\begin{array}{l}\text { All-in-spread drawn, the loan spread charged by the bank over LIBOR for the } \\
\text { drawn portion of the loan facility (obtained from Dealscan). }\end{array}$ \\
\hline UE (NUE) & $\begin{array}{l}\text { Unexpected earnings, the difference between actual EPS and the consensus } \\
\text { analyst forecast of EPS, deflated by the absolute value of the consensus analyst } \\
\text { EPS forecast. NUE }=1 \text { if } U E<0,0 \text { otherwise. }\end{array}$ \\
\hline $\begin{array}{l}\text { Pos_AA } \\
\text { (Neg_AA) }\end{array}$ & $\begin{array}{l}\text { Signed abnormal accruals (SAA), calculated using modified Jones model. } \\
\text { Pos_AA (Neg_AA) takes the value } 1 \text { if } S A A>0(<0) \text {, and } 0 \text { otherwise. }\end{array}$ \\
\hline D_AF & Takes value 1 if the number of analysts following $>4,0$ otherwise. \\
\hline Aft_RFD & Takes value 1 if the loan initiation quarter ended before Reg FD, 0 otherwise. \\
\hline FSIZE & Logarithm of the loan facility size. \\
\hline MATURITY & Loan facility maturity, measured in months. \\
\hline SECURE & Takes value 1 if the loan is secured, 0 otherwise. \\
\hline TAKEOVER & Takes value 1 if the loan purpose is takeover, 0 otherwise. \\
\hline LEVERAGE & Total Debt (item 51+ item 45) divided by Total Assets (item 44). \\
\hline RATING & $\begin{array}{l}\text { S\&P senior debt rating at close from Dealscan, recoded numerically from } 1 \text { to } \\
22 \text {, with } 1 \text { being 'AAA' and } 22 \text { being 'D', and } 0 \text { for 'not rated'. }\end{array}$ \\
\hline D_NR & Takes value 1 for firms that are not rated, 0 otherwise. \\
\hline ASSETS & Logarithm of Total Assets (item 44). \\
\hline TobinQ & $\begin{array}{l}\text { The market value of equity plus the book value of debt (item } 14 * \text { item } 61+\text { item } \\
44 \text { - item 59) divided by total assets (item } 44 \text { ). }\end{array}$ \\
\hline LAGRET & Cumulative stock return over the 12 months prior to the loan initiation. \\
\hline COMPLEX & $\begin{array}{l}\text { The average absolute value of analyst forecast error over the } 4 \text { fiscal quarters } \\
\text { prior to the loan quarter, deflated by the absolute value of last quarter's } \\
\text { consensus EPS forecast. }\end{array}$ \\
\hline EARN_VOL & $\begin{array}{l}\text { Standard deviation of quarterly earnings (item } 8 \text { ) over the } 4 \text { fiscal quarters prior } \\
\text { to the loan quarter, deflated by the standard deviation of quarterly CFO (item } \\
\text { 108) over the same period. }\end{array}$ \\
\hline RET_VOL & $\begin{array}{l}\text { Standard deviation of monthly returns over the } 12 \text { months prior to the loan } \\
\text { initiation month. }\end{array}$ \\
\hline
\end{tabular}




\section{BIBLIOGRAPHY}

Akerlof, G. (1970). “The market for 'Lemons': qualitative uncertainty and the market mechanism." Quarterly Journal of Economics 89: 488-500.

Allen, F. (1990). "The market for information and the origin of financial intermediation." Journal of Financial Intermediation 1: 3-30.

Allen, L., and Gottesman, A. (2005). "The informational efficiency of the equity market as compared to the syndicated bank loan market." SSRN working paper.

Allen, L., Guo, H., and Weintrop, J. (2004). "The information content of quarterly earnings in syndicated bank loan prices." SSRN working paper.

Altman, E., Gande, A, and Saunders, A. (2004). "Informational efficiency of loans versus bonds: evidence from secondary market prices." NYU working paper.

Asquith, P., Beatty, A., and Weber, J. (2005). "Performance pricing in bank debt contracts." Journal of Accounting and Economics 40: 101-128.

Bailey, W., Li, H, Mao, C., and Zhong, R. (2003). "Regulation Fair Disclosure and earnings information: market, analyst, and corporate responses." The Journal of Finance 58 (6): 2487-514.

Ball, R. (2001). "Infrastructure requirements for an economincally efficient system of public financial reporting and disclosure." Brookings-Wharton Papers on Financial Services, R. Litan and R. Herring (eds), Washington: Brookings Institution Press, 170-177.

Ball, R., Robin, A., and Sadka, G. (2005). "Is accounting conservatism due to debt or equity market? An international test of 'contracting' and 'value relevance' theories of accounting." Working paper, University of Chicago.

Barth, M., and Hutton, A. (2000). "Information intermediaries and the pricing of accruals." Working paper, Stanford University. 
Berger, A., and Udell, G. (1990). "Collateral, loan quality, and bank risk." Journal of Monetary Economics 25: 21-42.

Berlin, M., and J. Loeys. (1988). "Bond covenants and delegated monitoring." The Journal of Finance 43: 397-412.

Best, R., and Zhang, H. (1993). "Alternative information sources and the information content of bank loans." The Journal of Finance 48: 1507-1522.

Bharath, S. T., Sunder, J. and Sunder, S. (2007). "Accounting quality and debt contracting." Working Paper, Northwestern University.

Billet, M., Flannery, M., and Garfinkel J. (1995). "The effect of lender identity on a borrowing firm's equity return." The Journal of Finance 50: 699-718.

Billet, M., Flannery, M., and Garfinkel, J. (2006). “Are bank loans special? Evidence on the post-announcement performance of bank borrowers." Journal of Financial and Quantitative Analysis 41 (4): 733-751.

Bradshaw, M., Richardson, S., and Sloan, R. (2006). "The relation between corporate financing activities, analysts' forecasts and stock returns." Journal of Accounting and Economics 42: 53-85.

Brown, L., Rozeff, M. (1978). "The superiority of analyst forecasts as measures of expectations: Evidence from earnings." The Journal of Finance 33: 1-16.

Campbell, T., and Kracaw, W. (1980). "Information production, market signaling, and the theory of intermediation." The Journal of Finance 35: 863-882.

Dennis, S., Nandy, D., and Sharpe, I. (2000). "The determinants of Contract terms in bank revolving credit agreements." Journal of Financial and Quantitative Analysis 35(1): 87-110.

Dichev, I., and Skinner, D. (2002). "Large-sample evidence on the debt covenant hypothesis." Journal of Accounting Research 40: 1091-1123.

Durtschi, C., and Easton, P. (2005). "Earnings management? The shapes of the frequency distributions of earnings metrics are not evidence ipso facto." Journal of Accounting Research 43: 557-592.

Dye, R. 1985. "Disclosure of nonproprietary information." Journal of Accounting Research 23 (Spring): 123-145.

Fama, E. (1980). "Banking in the theory of finance." Journal of Monetary Economics 6: 39-57. 
Fama, E. (1985). "What is different about banks?" Journal of Monetary Economics 15: 29-39.

Fama, E., and French, K. (1997). "Industry Costs of Equity.” Journal of Financial Economics 43: 153-193.

Frankel, R., Kothari, S., Weber, J. (2006). "Determinants of the informativeness of analyst research." Journal of Accounting and Economics 41: 29-54.

Givoly, D. (1982). "Financial analysts' forecasts of earnings: a better surrogate for market expectations." Journal of Accounting and Economics 4 (2): 85-108.

Guedes, J., and Opler, T. (1996). "The determinants of the maturity of new corporate debt issues." Journal of Finance 51: 1808-1833.

Healy, P., and Palpu, K. (2001). "Information asymmetry, corporate disclosure, and the capital markets: A review of the empirical disclosure literature." Journal of Accounting and Economics 31: 405-440.

Heflin, F., Subramanyam, K.R., and Zhang, Y. (2003). "Regulation FD and the financial information environment: Early evidence." The Accounting Review 78 (1): 1-37.

Holthausen, R., and Watts, R. (2001). "The relevance of the value-relevance literature for financial accounting standard setting." Journal of Accounting and Economics 31: $3-75$.

James, C. (1987). "Some evidence on the uniqueness of bank loans." Journal of Financial Economics 19: 217-235.

Jorion, P., Liu, Z., and Shi, C. (2005). "Informational effects of regulation FD: Evidence from rating agencies." Journal of Financial Economics 76: 309-330.

Ke, B., and Yu, Y. (2005). "Do Analysts merely serve as a conduit for management's private information? Evidence from their stock recommendation around Regulation FD.” Working Paper, Pennsylvania State University.

Klein, A. (1990). "A direct test of the cognitive bias theory of share price reversals." Journal of Accounting and Economics 13: 155-166.

Kothari, S. P., Shu, S., and Wysocki, P. (2006). "Do managers withhold bad news?" Working paper, MIT.

Lang, M., and Lundholm, R. (1996). "Corporate disclosure policy and analyst behavior." The Accounting Review 71(4): 467-492. 
Leland, H., and Pyle, D. (1977). "Information asymmetries, financial structure, and financial intermediation." The Journal of Finance 32: 371-387.

Leuz, C., and Verrecchia, R. (2000). "The economic consequences of increased disclosure.” Journal of Accounting Research 38: 91-125.

Lummer, S., and McConnell, J. (1989). "Further evidence on the bank lending process and the capital-market response to bank loan agreements." Journal of Financial Economics 25: 99-122.

Manove, M., Padilla, A. J. and Pagano, M. (2001). "Collateral vs. project screening: a model of lazy banks." RAND Journal of Economics 32 (4): 726-744.

Milgrom, P. (1981). "Good news and bad news: Representation theorems and applications." Bell journal of Economics 12 (Autumn): 380-391.

Moerman, R. (2006). "The role of information asymmetry and financial reporting quality in debt contracting: Evidence from the secondary loan market." SSRN working paper.

Mohanram, P., and Sunder, S. (2006). "How has Reg FD affected the operations of financial analysts?" Contemporary Accounting Research 23 (2): 427-464.

O'Brien, P. (1988). “Analysts' forecasts as earnings expectations.” Journal of Accounting and Economics 10: 53-83.

Petersen, M. (2005). "Estimating standard errors in finance panel data sets: Comparing approaches." Kellogg Finance Department Working Paper No. 329.

Strahan, P. (1999). "Borrower risk and the price and non-price terms of bank loans." Staff Report 90, Federal Reserve Bank of New York.

Sufi, A. (2007). "Information asymmetry and financing arrangements: Evidence from syndicated loans." The Journal of Finance 62 (2): 629-668.

Sunder, J. (2006). "Information spillover and capital structure.” Working Paper, Northwestern University.

Wang, I. (2006). "Understanding private earnings guidance and its implications for disclosure regulation." Working Paper, Michigan State University. 